\title{
Metody badań terenowych $w$ analizie zmian uksztaltowania akumulacyjnych odcinków wydm nadmorskich polskiego wybrzeża
}

\author{
The methods of field research in the analysis of accumulative foredunes development on the \\ Polish coast
}

\author{
Tomasz A. Łabuz \\ Instytut Nauk o Morzu, Uniwersytet Szczeciński, Szczecin; e-mail: labuztom@univ.szczecin.pl
}

Zarys treści: W pracy przedstawiono metody badań zastosowanych do analizy zmian rzeźby wydm nadmorskich na akumulacyjnych odcinków polskiego wybrzeża. Badania realizowane były przy użyciu różnych technik geodezyjnych, m.in. z zastosowaniem stabilizowanych w podłożu reperów, niwelatora, teodolitu. W ostatnich latach korzystano z nowoczesnych urządzeń, działających w oparciu o satelitarną lokalizację badanych miejsc, takich jak dGPS RTK oraz RTK GPS. Prace realizowane były w różnych skalach przestrzennych: od pomiarów punktowych, liniowych do powierzchniowych. Celem podjętych badań morfometrycznych było przetestowanie różnych technik i urządzeń badawczych pod kątem ich użyteczności w określaniu dynamiki współczesnej rzeźby najmłodszych wydm nadmorskich. Przedstawiono ustalenia potrzebne do klasyfikacji form i wskazania kierunku rozwoju wybrzeży mierzejewo-wydmowych w warunkach zmian klimatu i presji człowieka. Praca prezentuje możliwości wykorzystania dostępnych technik do określania parametrów zmian niestabilnej rzeźby wydm nadmorskich w różnych skalach czasowo-przestrzennych. W pracy zawarto przykładowe wyniki dynamiki rzeźby wydm i charakterystycznych wskaźników ich zmian oraz wybrane możliwości prezentacji graficznej. Badania prowadzono w wybranych miejscach obejmując $20 \%$ długości całego polskiego wybrzeża.

Słowa kluczowe: wydmy przednie, morfodynamika, metody badań morfometrycznych, polskie wybrzeże Bałtyku

\begin{abstract}
The paper presents field research methods used to analyse relief changes of coastal dunes on the accumulative sections of the Polish coast. The research were carried out using a variety of surveying techniques, among others, using stabilized in the ground rods, leveler, theodolite. In recent years, the use of modern equipment, operating on the basis of satellite location, such as dGPS RTK and GPS RTK were used too. The work was carried out at different spatial scales, from the measurement point to line and the surface. The aim of this study was to test various morphometric techniques and research devices for their usefulness in determining the dynamics of contemporary relief of the youngest coastal dunes - foredunes. Paper also presents the findings needed to classify the relief forms and to indicate the direction of sand barrier and dunes development in conditions of climate change and human pressure. Work presents the possibilities of available techniques use, to characterise changes of unstable sand dunes in different time and space scales. This paper contains examples of the results on dune relief research dynamics and selected graphical presentation possibilities. Data from the realised studies are useful for different time scale comparison as vectors, volumes or 3D pictures. Those methods are clearly showing accumulation tendencies of some sections of the coast in different time and surface scale. The presented studies are covering almost $20 \%$ of dunes on the Polish coast.
\end{abstract}

Keywords: foredunes, morphodynamics, methods of morphometric research, Polish Baltic coast

\section{Wprowadzenie}

Badania przekształceń ukształtowania dynamicznych wydm przednich są istotnym elementem analiz oddziaływania czynników i uwarunkowań morfolitodynamicznych oraz prognoz rozwoju rzeźby wybrzeża (Rosa 1963, Borówka M. 1979, Hesp 1984, Carter, Wilson 1990, Da-
vidson-Arnott, Law 1996). Procesy eoliczne kształtujące wydmy nadmorskie uwarunkowane są wieloma czynnikami, między innymi lokalnymi warunkami aerodynamicznymi, prędkością i częstotliwością wiatru, bilansem osadu na plaży, obecnością roślinności i składem granulometrycznym osadu (m.in. Bird 2002). Czynniki te sta- 
nowią podstawę badań środowiska wydm nadmorskich. W celu ich analizy niezbędne jest wykonywanie pomiarów morfometrycznych w różnych skalach czasowo-przestrzennych. Stosowane w badaniach metody mają na celu korelację zarejestrowanych form eolicznych z tempem ich wzrostu, wywołanym przez uwarunkowania antropogeniczne, klimatyczne, hydrologiczne i litologiczne. Analizowane są również okresy, w których na rozwój wydm oddziałują wyżej wymienione czynniki i uwarunkowania, co jest tematem wielu prac badawczych (Carter, Wilson 1990, Davidson-Arnott, Law 1990, 1996, Pye, Blott 2008, Hesp 2013). Dlatego pomiary powinny być dostosowane do zmiennych warunków zewnętrznych, mających wpływ na dynamikę wydm. Zmiany te, to przede wszystkim okresowa lub stała akumulacja osadu na brzegu, rozwój plaż oraz rekonstrukcja podmytych wałów wydmowych lub utworzenie nowych generacji wydm nadmorskich. Określenie, które zjawiska sprzyjają rozwojowi wydm, ich bioróżnorodności oraz stabilności morfologicznej nadbrzeża, poprawiają bezpieczeństwo terenów zurbanizowanych na zapleczu brzegu i są kluczowe w interpretacji i prognozowaniu zmian wybrzeży wydmowych.

Celem niniejszego opracowania jest przedstawienie zastosowania różnych metod kartowania terenowego do analizy zmian przestrzennych i czasowych rzeźby wydm nadmorskich na odcinkach akumulacyjnych. W pracy zaprezentowano stosowaną metodykę i technikę badań terenowych i opracowań kameralnych. Stosowane w pomiarach urządzenia zostały szerzej opisane w innych publikacjach (Labuz 2007, 2009, 2011, Łabuz, Sławińska, Osóch 2012, Łabuz, Osóch 2013, Łabuz 2014c, 2014d, 2015). Ponadto zaprezentowano niektóre wyniki ukazujące tempo rozwoju wydm nadmorskich na akumulacyjnych odcinkach brzegu morskiego w Polsce. Wśród czynników i uwarunkowań analizowanych w prezentowanych badaniach są oddziaływania spiętrzeń sztormowych, ekspozycja brzegu względem dominujących kierunków wiatrów, a także rozmieszczenie roślinności wydmowej.

\section{Metody i obszar badań}

Badania realizowane są na całym wybrzeżu Polski, od Mierzei Wiślanej po Mierzeję Bramy Świny, na wszystkich odcinkach wybrzeża wydmowego wykazującego tendencje akumulacyjne (ryc. 1C): 1) Mierzeja Wiślana: Piaski i Przebrno, 2) ujście przekopu Wisły: Jantar, Mikoszewo, Sobieszewo, 3) Półwysep Helski: cypel, rejon

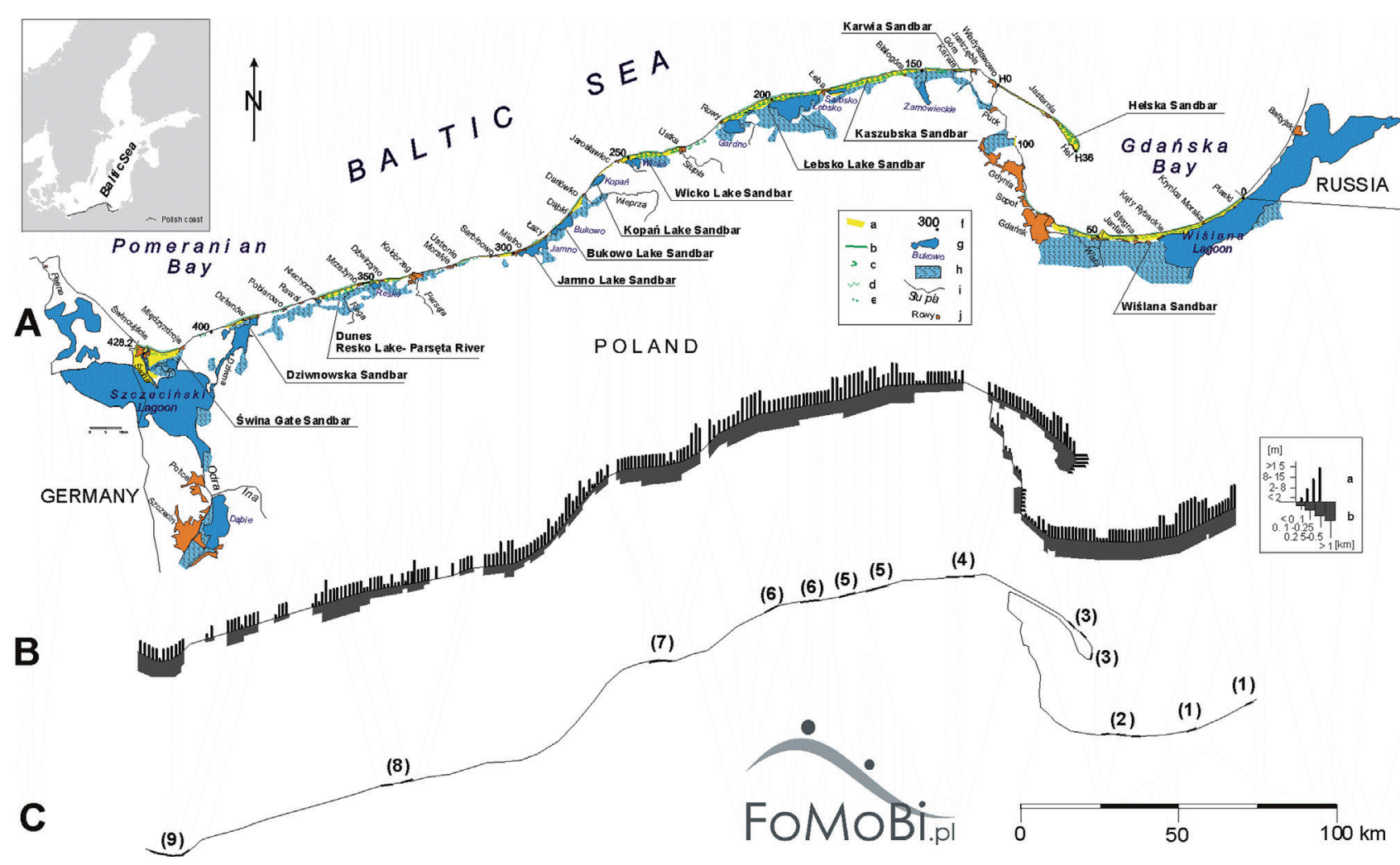

Ryc. 1. Polskie wybrzeże wraz z rozmieszczeniem wydm nadmorskich

A - mapa, a - mierzeje, b - wydmy przednie, c - śródlądowe wydmy, barchany dawniej wędrujące, d - śródlądowe wydmy, poprzeczne, dawniej wędrujące, e - wydmy na podłożu morenowym, f - kilometraż wybrzeża, $\mathrm{g}$ - jeziora, $\mathrm{h}$ - tereny podmokłe, $\mathrm{i}$ - rzeki, $\mathrm{j}$ - osadnictwo. B - rozmieszczenie wybrzeży wydmowych, a - wysokość wybrzeża wydmowego, b - szerokość mierzei. C - rejony prowadzenia badań na odcinkach akumulacyjnych, 1-9, opis w tekście

Fig. 1. Polish Baltic Sea coast

A- coast map, a - sandbars, $\mathrm{b}$ - foredunes, $\mathrm{c}$-formerly shifting parabolic and barchan dunes, $\mathrm{d}$ - formerly shifting transverse ridges, $\mathrm{e}$ - dunes on moraine coast, $\mathrm{f}$ - coast kilometrage, $\mathrm{g}$ - lakes, $\mathrm{h}$ - wetlands, swamps, $\mathrm{i}$ - rivers, $\mathrm{j}$ - settlement. $\mathrm{B}$ - dune coast location, $\mathrm{a}$ - dune coast height, $\mathrm{b}-$ sand barrier width. $\mathrm{C}-$ investigated study areas $1-9$, description in text 
Tabela 1. Zdarzenia ponadprzeciętne w okresie pomiarów 2010-2015, dane Kapitanat Portu Świnoujście

Table 1. The events above average in the period of measurements 2010-2015, data the Harbour Office in Świnoujście

\begin{tabular}{|c|c|c|c|c|c|c|}
\hline \multirow[b]{2}{*}{$\begin{array}{l}\text { Nazwa zjawiska } \\
\text { Name of the event }{ }^{1}\end{array}$} & \multicolumn{2}{|c|}{ Data/Date } & \multicolumn{2}{|c|}{ Spiętrzenia sztormowe/Storm surges } & \multicolumn{2}{|c|}{ Wiatr/Wind } \\
\hline & Rok/year & $\begin{array}{l}\text { Dzień miesiąc/ } \\
\text { day month }\end{array}$ & $\begin{array}{c}\text { Maks p. morza/ } \\
\text { max. sea level [m a.s.l.] }\end{array}$ & $\begin{array}{c}\text { Falowanie/ } \\
\text { sea waving [Bft] }\end{array}$ & $\begin{array}{r}\text { Kierunek/ } \\
\text { direction }\end{array}$ & $\begin{array}{c}\text { Predkość/ } \\
\text { velocity }\left[\mathrm{m} \mathrm{s}^{-1}\right]\end{array}$ \\
\hline Bez nazwy/No name & 2010 & $15 / 16.12$ & 1,00 & 6 & NNE & $14-16$ \\
\hline Joachin & 2011 & $15 / 17.12$ & 1,00 & $6-7$ & NW & $15-17$ \\
\hline Andrea & 2012 & $4 / 6.01$ & 1,00 & 7 & NNW & $13-15$ \\
\hline Andrea 2 & 2012 & $12 / 14.01$ & 1,30 & 10 & $\mathrm{NW}-\mathrm{N}$ & $14-17$ \\
\hline Bez nazwy/no name & 2013 & $23 / 24.11$ & 0,50 & $4-5$ & $\mathrm{~N}$ & $12-14$ \\
\hline Xavier & 2013 & $6 / 7.12$ & 0,90 & $9-12$ & NW-N & $18-23$ \\
\hline Aleksandra & 2014 & $12 / 14.12$ & $-0,30$ & $3-4$ & WSW & $19-20$ \\
\hline Bez nazwy/No name & 2014 & $21 / 23.12$ & 0,50 & $4-5$ & W & $20-22$ \\
\hline Bez nazwy1/No name1 & 2015 & 03/04.01 & 0,90 & $6-8$ & W-WNW & $9-12$ \\
\hline Bez nazwy2/No name2 & 2015 & $07 / 08.02$ & 1,20 & $7-9$ & $\mathrm{~N}-\mathrm{NNW}$ & $12-16$ \\
\hline
\end{tabular}

1 -źródło: http://pl.wikipedia.org/wiki/Orkany_w_Polsce

Hel-Bór, 4) Mierzeja Karwieńska, 5) Mierzeja Kaszubska: Białogóra i Stilo, 6) Mierzeja Łebska: rejon wydmy Łąckiej i wydmy Czołpińskiej, 7) Mierzeja Jeziora Wicko, 8) pas wydmowy Rogowo (Mierzeja Jeziora Resko) i Grzybowo, 9) Mierzeja Bramy Świny. Teren badań i opis czynników decydujących o jego przekształceniach omówiono w innych publikacjach (Łabuz 2013a, Łabuz $i$ in. 2013). Miał on na celu określenie rozmieszczenia i stanu odcinków akumulacyjnych polskiego wybrzeża oraz dynamiki i zagrożeń wydm przednich na polskim wybrzeżu, poprzez ich powtarzalną inwentaryzację przestrzenną. Badania monitoringowe są obecnie kontynuowane pod szyldem projektu własnego FoMoBi 2.0 z odniesieniem do wyników wcześniejszych prac badawczych z lat 1997-2011.

Na potrzeby analiz morfometrycznych i tempa rozwoju wydmy przednie poddano szeroko zakrojonym badaniom topograficznym. Obiekt badań - wydmy przednie, to wałowe formy eoliczne składające się z pojedynczych pagórów i kopuł, formowanych na zapleczu plaży w warunkach akumulacji wybrzeża (definicja za Hesp 1984). Formy te są wskaźnikiem tendencji akumulacyjnych i obiektem szeregu interpretacji zmierzających do określenia zmian wybrzeża oraz działających na nie uwarunkowań.

Podstawowe pomiary rzeźby terenu w wyznaczonych uprzednio miejscach wykonywano dwukrotnie w ciągu roku - wiosną i jesienią. Umożliwiało to rejestrację zmian ukształtowania wydm:

- jaka zaszła w ciągu jednego cyklu wegetatywnego roślin i określenie ich wpływu na zmianę rzeźby,

- wywołanych przez sezonowe uwarunkowania klimatyczne i hydrologiczne,

- w określonych przedziałach czasowych celem określenia sezonowych lub rocznych zmian.

W miarę zaistniałych potrzeb realizowano pomiary, których celem było określenie wpływu zjawisk ekstremalnych na zmiany rzeźby wydm wybrzeża, t.j. okresów występowania spiętrzeń sztormowych lub wiatrów o bardzo dużej prędkości. W projekcie takie dodatkowe prace realizowano przy okazji wystąpienia spiętrzeń sztormowych: dwóch z 6 i 14 stycznia 2012 r., spiętrzenia sztormowego z 6/7 grudnia 2013 r. spowodowanego przez huragan Xavier, podczas huraganu Aleksandra z dni 12/14 i kolejnego z 21/23 grudnia 2014 r. oraz sztormów ze stycznia 2015 r. (Tabela 1), Prezentowane wyniki obejmują przede wszystkim badania prowadzone od 2010 do $2015 \mathrm{r}$.

Stosowane techniki pomiarów terenowych i wykorzystane własne ułatwienia zbierania danych zaprezentowano poniżej. W śród nich zaprezentowano jakość wyników uzyskanych metodami pomiarów punktowych, liniowych i powierzchniowych z zastosowaniem różnego typu urządzeń pomiarowych.

\section{Punktowe pomiary zmian wysokości}

Metoda ta, w swoim założeniu daje szczątkowe informacje o zmianach rzeźby terenu. Nadaje się bardziej do badań w przypadku potrzeby stwierdzenia maksymalnych zmian wysokości w konkretnych punktach lub na obszarach prac pilotażowych. Sprawdza się jednak na obszarach, gdzie stwierdzono ekstremalne zmiany rzeźby poza obrębem danego poligonu badawczego, wymaganych do analizy wyników z obszaru szerszego. Pomiary te można realizować zarówno za pomocą prostych technik z zastosowaniem stabilizowanych $\mathrm{w}$ podłożu palików - reperów oraz za pomocą metod geodezji optycznej czy też cyfrowej, bazującej na lokalizacji satelitarnej punktów terenu.

Pomiary te mogą być podzielone na dwie grupy:

- odczytów wysokości w wybranych, interesujących punktach strefy wydm, np.: wysokość podnóża wydmy, grzbietu, głębokość rynny, wysokość względna podcięcia abrazyjnego,

- odczytów wysokości wzdłuż wyznaczonych transektów odpowiadających np. kierunkowi przebiegu danej formy: dno rynny, przekrój grzbietu, oś grzbietu, szerokość plaży górnej.

W najprostszym ujęciu pomiary te polegają na określeniu odległości za pomocą taśmy mierniczej i wzrokowym odczycie różnicy wysokości z tyczek posiadajacych ustalona podziatkę wysokości, tak zwana Metoda Emer'e- 
go (Andrade, Ferreira 2006, Harley i in. 2011). W kilku rejonach zastosowano metodę odczytu punktowego, polegającą na zastabilizowaniu w podłożu reperów na wydmach embrionalnych rozmieszczonych nieregularnie na plaży, tak by móc określać ich godzinną lub miesięczną zmianę wysokości.

Przykład wyników takich badan prowadzonych podczas trwania huraganu Xavier w grudniu 2013 r. zawiera tabela 2. Pomiar taki pozwalał na określenie zmian wysokości wybranych form terenu w krótkim odstępie czasu, bez użycia innych urządzeń mogących wydłużyć pomiar czasowo. Odczyty długości reperów wystających nad poziom gruntu stanowiły podstawę analiz zmian wysokości w tych miejscach.

W innym celu stosowano odczyty wysokości palików rozmieszczonych w poprzek całego wału wydmy przedniej (Łabuz 2009). Drewniane repery stabilizowano w ruchomym podłożu w odstępach metrowych. Odczytując taśmą mierniczą wysokość repera wystającego nad podłożem, określano zmiany wysokości tego podłoża pomiędzy okresami odczytów. Pomiary takie dają orientację o zmianach względnych wysokości punktów podłoża na większym obszarze. Szybki odczyt bez skomplikowanego sprzętu jest atutem w pracach wymagających natychmiastowych wyników. Pomiary punktowe zmian rzeźby stosowano również na potrzeby określenia wysokości skarp erozyjnych. W tym celu stosowano taśmę mierniczą lub sznurek, przykładany do pionowych ścian podciętej wydmy przedniej. Na tej podstawie określano krótkookresowe zmiany względne wysokości, które mogły być dowiązane do punktów własnej osnowy geodezyjnej.

W ostatnich trzech latach punktowe pomiary zmian rzeźby wydm embrionalnych realizowano przy użyciu urząazzenia dGPS RTK marki Hiper II i GPS RTK Hiper SR firmy Topcon. Zalety tych urządzeń oraz sposób ich funkcjonowania zostały krótko opisane poniżej oraz szerzej w odrębnej publikacji (Łabuz 2015).

Możliwość poznania wysokości i współrzędnych punktu w czasie rzeczywistym za pomocą urządzeń GPS uniezależnia badacza od potrzeby stabilizowania reperów na podłożu o znanej i niezmiennej wysokości i dowiązywaniu pomiaru do istniejącej lub własnej sieci geodezyjnej (Łabuz, Sławińska, Osóch 2012). Te elektroniczne urządzenia nie zawsze mogą być jednak stosowane. Odczyt poprzez zdalne połączenie z siecią GPS staje się niemożliwy w trudnych warunkach pogodowych, zwłaszcza podczas zjawisk ekstremalnych, które np. wywołują procesy eoliczne. Duża prędkość wiatru, potok piaszczysty lub opad deszczu ograniczają stosowanie urządzeń innych, niż metody proste z zastosowaniem reperów. Używanie tych urzadzeń do celów doktadnego pomiaru i precyzji nie jest niemożliwe w okresach wystapienia trudnych warunków pogodowych.

Wyniki badań punktowych rzeźby, to zmiany względne wysokości podłoża w czasie, np. co godzinę podczas zdarzeń o charakterze ekstremalnym, zmiany miesięczne, a nawet roczne. Ponadto uzyskuje się informacje o wy- miarach skarp, podcięć deflacyjnych i abrazyjnych oraz zagłębień deflacyjnych terenu.

\section{Pomiary z zastosowaniem profili poprzecznych do brzegu}

Najczęściej wykonywanymi badaniami są pomiary rzeźby terenu wzdłuż wyznaczonych profili skierowanych poprzecznie do brzegu (ryc. 4A). Profile oznaczone są w terenie za pomocą umiejscowionych na stabilnym podłożu reperów, od których przez ruchome podłoże wydm i plażę do linii wody ustawiane są paliki (Łabuz 2009, Łabuz, Osóch 2012). Lokalizacja stawianych palików podyktowana jest obserwowanymi zmianami ukształtowania rzeźby terenu. Przy tak ustawionych palikach wykonywane są odczyty wysokości za pomocą np. łaty, niwelatora i taśmy mierniczej. Dane wstawiane są w specjalnie skonstruowany arkusz własnego pomysłu, umożliwiający dodanie szkicu terenu oraz zasięgów roślinności. Przy użyciu kompasu geologicznego i zastabilizowanych w podłożu reperów na linii profilu wyznaczany jest azymut, co pozwala na uzyskanie niezmienionego przebiegu linii pomiarowej podczas następnych pomiarów. Prace przy pomocy urządzeń optycznych i przy odpowiedniej adaptacji są możliwe również nocy, a także możliwe w trudnych warunkach atmosferycznych. Łącznie wykonywane jest około 110 profili w wybranych rejonach polskiego wybrzeża, skupionych po 5-8 na odcinkach akumulacyjnych i zlokalizowanych w odległościach od 0,3 do $1 \mathrm{~km}$ od siebie (Labuz 2014a, 2014b). Profile wykonywane są najczęściej przy pomocy niwelatora $\mathrm{Al} 20$, pracującego z dokładnością do $\pm 0,5 \mathrm{~cm}$ wysokości. Można również prowadzić taki pomiar za pomocą urządzeń RTK GPS. W takiej sytuacji należy liczyć się ze zmiennymi warunkami pogodowymi, wydłużającymi prace terenowe. Metoda ta, stosowana przez wielolecia, daje dobre rezultaty poznania zmian rzeźby wybrzeża wydmowego, na podstawie powtarzalnych profili wykonywanych w tych samych miejscach (m.in. Hesp 2013). Wyniki to zapis liniowy zmian ukształtowania rzeźby terenu, który można przedstawić za pomocą zmian objętości osadu na zadanym odcinku profilu.

Dane z badań terenowych analizowane są w arkuszach programu Excel, celem uzyskania zestawienia zmienności rzeźby na profilach pomiędzy poszczególnymi pomiarami. Przy pomocy programu Grapher lub Grab it! wykonywano digitalizację profili, polegającą na cyfrowym odczycie wysokości $H$ co $1 \mathrm{~m}$ długości każdego profilu. Dokładność pomiaru wysokości na profilach ustalono na nie mniejszą niż $1 \mathrm{~cm}$. Wynika to z błędu terenowego zależnego obserwatora ustawiającego łatę na luźnym piaszczystym podłożu, powodującym zapadanie miernika w grunt. Wartości zmian wysokości zebranych co $1 \mathrm{~m}$ sumowano w obszarze wydzielonych form rzeźby, takich jak: wał wydmy przedniej, pas plaży górnej lub całej plaży: $\sum H_{x L}$, gdzie: $x$ - kod formy, $L$ - suma szerokości formy na profilu w metrach. Zmiany wysokości form co $1 \mathrm{~m}$ długości profilu $\left(\Delta H_{i x}\right)$ określano odejmując 


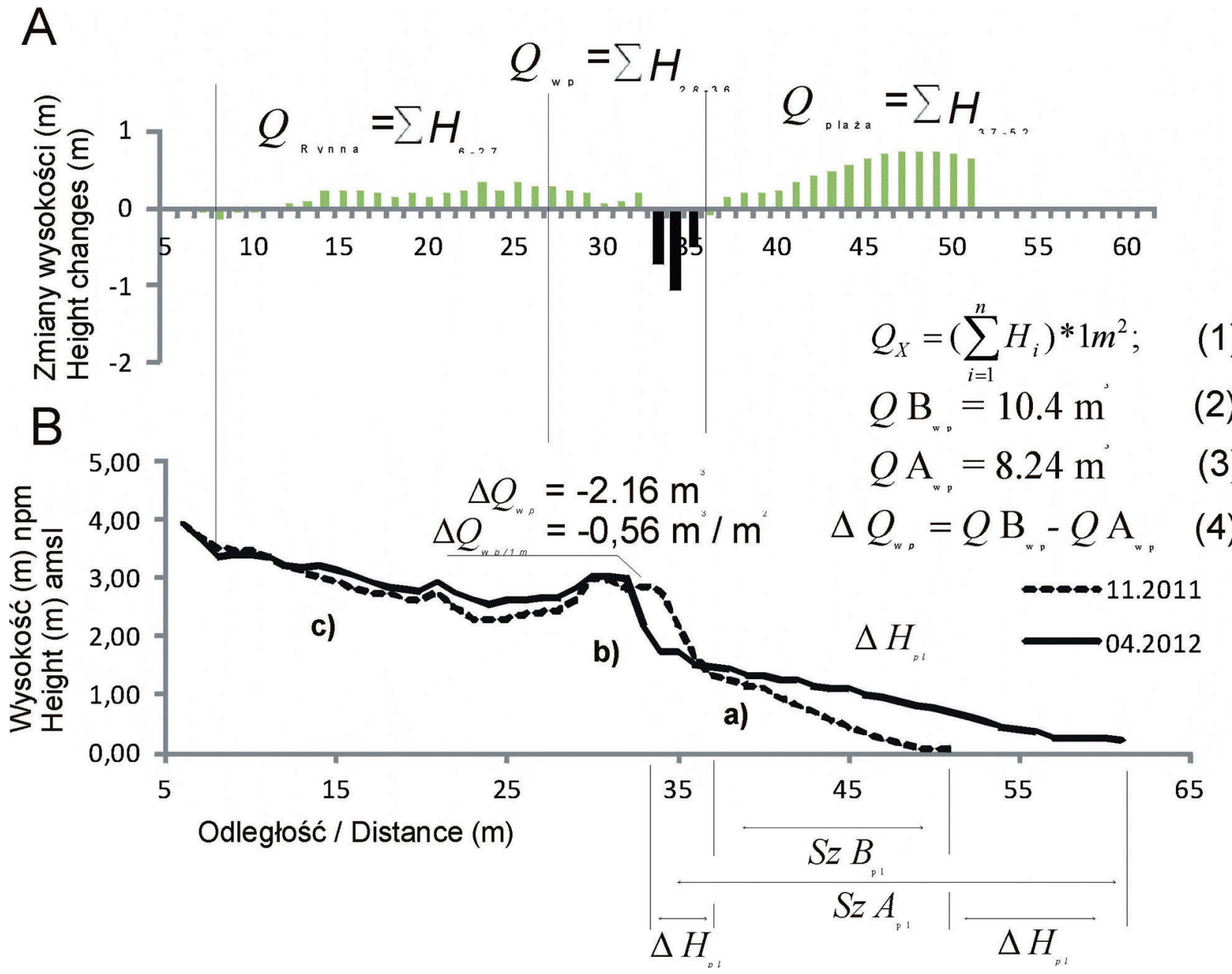

Ryc. 2. Procedura obliczeń objętości form rzeźby z profilu poprzecznego

A - słupki morfo-dynamiczne, pokazujące zmiany wysokości na profilu uzyskane na podstawie digitalizacji. B - nałożone profile, pokazujące warstwę dynamiczną oraz zmiany ukształtowania terenu, 1 - suma objętości osadu formy na danym odcinku, 2 - objętość osadu przed, 3 - objętość osadu po, 4 - różnica objętości osadu

Fig. 2. The volume calculation procedure of form relief based on the profile cross-section

A - morphodynamic piles, showing the height change obtained on the basis of profile digitization. B - superposed profiles, showing the dynamic layer and changes in terrain, 1 - sediment volume of the form on section, 2 - sediment volume before, 3 - sediment volume after, 4 - sediment volume difference

obliczone wysokości z pomiaru późniejszego $\left(\mathrm{H} b_{i x}\right)$, do $\left(\mathrm{H} a_{i x}\right)$ wcześniejszego, co można wyrazić jako:

$$
\Delta H_{i x}=H b_{i x}-H a_{i x} .
$$

Zmiany wysokości dla formy $\left(H_{i x}\right)$ przeliczano na objętość osadu przypadającą 1 metr kwadratowy powierzchni formy $(x)$. Suma zmian wysokości dla danej formy $(x)$ była podstawą do obliczenia zmian objętości osadu, przypadającej na $1 \mathrm{~m}^{2}$ lub na całą powierzchnię analizowanej formy:

$$
\Delta Q_{X}=\left(\Sigma H_{i}\right) \times 1 \mathrm{~m}^{2}
$$

Po podzieleniu przez sumę szerokości formy otrzymywano objętości osadu na każdym metrze kwadratowym profilu. Uzyskane dane z profilowań to: zmiany szerokości i wysokości form, zmiany wysokości na każdy $1 \mathrm{~m}$ długości profilu, zmiany położenia podstawy i krawędzi (grzbietu) wydmy, objętości osadu form rzeźby w metrach sześciennych oraz zmiany objętości osadu form na każdy metr kwadratowy powierzchni wzdłuż profilu (ryc. 2). Metoda ta została wykorzystana (i szerzej opisana) m.in., do pomiarów krótkookresowych zmian rzeźby pod wpływem spiętrzeń sztormowych (Łabuz 2011, 2014b). Daje też dobre rezultaty przy wieloletniej analizie zmian rzeźby wydm nadmorskich (Łabuz 2009, 2014a). Badania pozwalają określić zmiany wysokości oraz objętości osadu budującego luźne podłoże wydm i plaży.

\section{Powierzchniowe pomiary rzeźby w poletkach}

Doświadczenia terenowe służące do określenia zmian rzeźby terenu $\mathrm{z}$ wykorzystaniem pomiarów topograficznych na poletkach powierzchniowych w Polsce prowadzone były przez Borówkę (1979). Badania te realizowane były na powierzchni $2000 \mathrm{~m}^{2}$, a odczyt wysokości co $2 \mathrm{~m}^{2}$. W literaturze światowej metoda ta powszechnie sto- 


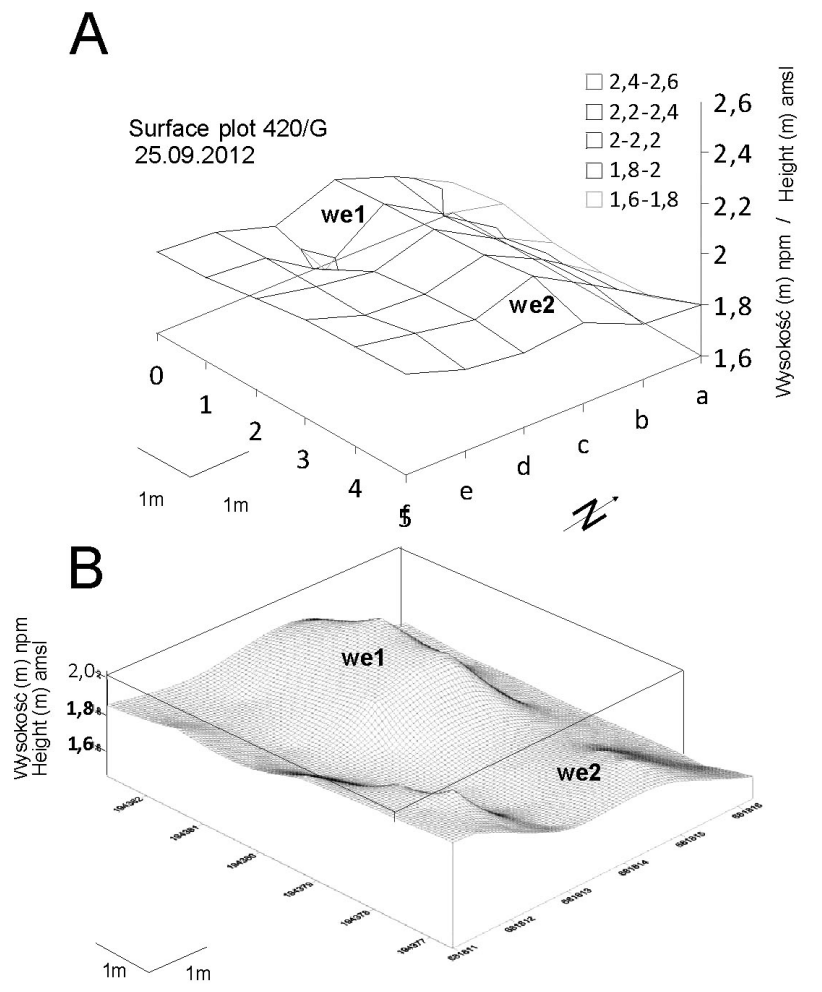

Ryc. 3. Przykład dokładności pomiaru powierzchownego poletka badawczego wykonanego dwoma technikami

A - poletko wykonane przy użyciu niwelatora $\mathrm{z}$ odczytem wysokości co $1 \mathrm{~m}^{2}$, B - poletko wykonane za pomocą GPS RTK z odczytam wysokości co kilka cm, we1, we2 - wydmy embrionalne

Fig. 3. Example of accuracy measurement of the plot that were made using two surveying techniques

A - plot made using a leveler with altitude readings at $1 \mathrm{~m}^{2}$, $\mathrm{B}$ - plot made using RTK GPS with readings each few $\mathrm{cm}$, we1, we 2 - embryo dunes

sowana jest do pomiarów zmian rzeźby i dynamiki procesów eolicznych (np. Davidson-Arnott, Law 1990). Prace takie stosowano w Polsce dotychczas w latach 2003-2008 na Mierzei Bramy Świny (Łabuz 2007, 2009). Technikę pomiaru na poletkach powierzchniowych wykorzystano również w badaniach na całym wybrzeżu w latach 20102014.

Obecnie, w badaniach powierzchniowych zmian rzeźby terenu coraz częściej odchodzi się od optycznych pomiarów niwelacyjnych na danej powierzchni, na rzecz wykorzystania bardziej zaawansowanych technicznie przyrządów i urządzeń odczytujących, jak kratownice z ruchomymi ramionami nakładane na rzeźbę terenu lub odbiorniki GPS RTK. Różnice dokładności morfologii uzyskanej za pomocą niwelatora i GPS RTK pokazuje ryc. 3 . W badaniach tych analizowano pomiary z 20 poletek powierzchniowych o wymiarach $5 \times 5 \mathrm{~m}$, posiadających całkowitą powierzchnię $25 \mathrm{~m}^{2}$. Poletka zlokalizowano na plaży górnej, obejmując pomiarem formy embrionalne wydm (ryc. 4B). Poletka zlokalizowano na wszystkich obszarach pomiarowych wyróżnionych w tekście i realizowanych w projekcie FoMoBi.
Przed każdym z pomiarów odnajdywane było położenie poletek za pomocą współrzędnych i domiarów od reperów umieszczonych w podłożu stabilnym (porośniętym przez mchy, co gwarantuje niezmienność wysokości pomiędzy pomiarami). Obszar pomiaru wytyczano za pomocą tyczek i taśmy mierniczej, co ułatwiało prowadzenie pomiarów i wykonywanie szkiców. Odczyty wykonywane były za pomocą metody geodezyjnej przy użyciu niwelatora i łaty mierniczej lub mobilnego odbiornika RTK GPS. Wartości wysokości odczytywane były na przecięciach siatki kwadratów pokrywających poletko co $1 \mathrm{~m}$. Uzupełnieniem pomiaru był wykonywany rysunek rzeźby, na który w siatce poletka nanoszono, m.in. rozmieszczenie roślin, bruku muszlowego i ripplemarków. Dane te umożliwiały korelację zmian wysokości na danej powierzchni w odniesieniu, np. do rozmieszczenia roślinności.

Cyfrowy zapis wysokości rzeźby w poletku uzyskiwano w arkuszach Excel. Po wykonaniu powtarzalnych pomiarów odczytywano różnice zmian wysokości przypadające na $25 \mathrm{~m}^{2}$ oraz zmiany objętości osadu na powierzchni objętej poletkiem (ryc. 3A). Metoda ta pozwala na łatwe $\mathrm{i}$ analitycznie poprawne przejście $\mathrm{z}$ wartości zmian powierzchniowych na objętości osadu ulegające zmianom. Na podstawie zmian wysokości w określonym polu powierzchniowym można uzyskać parametry objętościowe osadu: zmian rzeźby pomiędzy pomiarami - dynamikę rzeźby i zmiany sumaryczne - bilans osadu (ryc. 8). Osobnym wynikiem są dane do korelacji pokrycia powierzchni roślinnością w stosunku do uzyskanych zmian wysokości.

\section{Wielkopowierzchniowe pomiary rzeźby}

Pomiary rzeźby terenu i jej zmiany na większej powierzchni są możliwe od kilku lat przy użyciu nowoczesnego, specjalistycznego sprzętu, m.in.:

- odbiorników GPS RTK (Real Time Kinematic),

- skanerów TLS (Terriestial Laser Scanner).

Urządzenie GPS RTK działa, łącząc się z dostępnymi satelitami GNSS (Global Navigation Satelite System) i GONASS (Globalnaja nawigacionnaja sputnikowaja sistiema), w celu podania lokalizacji - współrzędnych geograficznych oraz wysokości nad poziom morza. Współrzędne mogą też być pozyskane $\mathrm{z}$ tzw. sieci poprawek, dostarczanych w czasie rzeczywistym z systemu ASG EUPOS lub sieci TPI Net PRO (w Polsce). Pomiary wykonywane są jako odczyty położenia i wysokości punktów $(x, y, z)$ na danej powierzchni (Pardo-Pascual i in. 2005, Harley i in. 2011, Jeong-Min i in. 2013).

Skaner TLS, to wysoko zaawansowane urządzenie wysyłające wiązkę lasera, która po odbiciu od przeszkody daje dokładne położenie elementów względem siebie i lokalizacji emitera (Feagin i in. 2012, Pilecki 2012, Montreuil $\mathrm{i}$ in. 2013). 

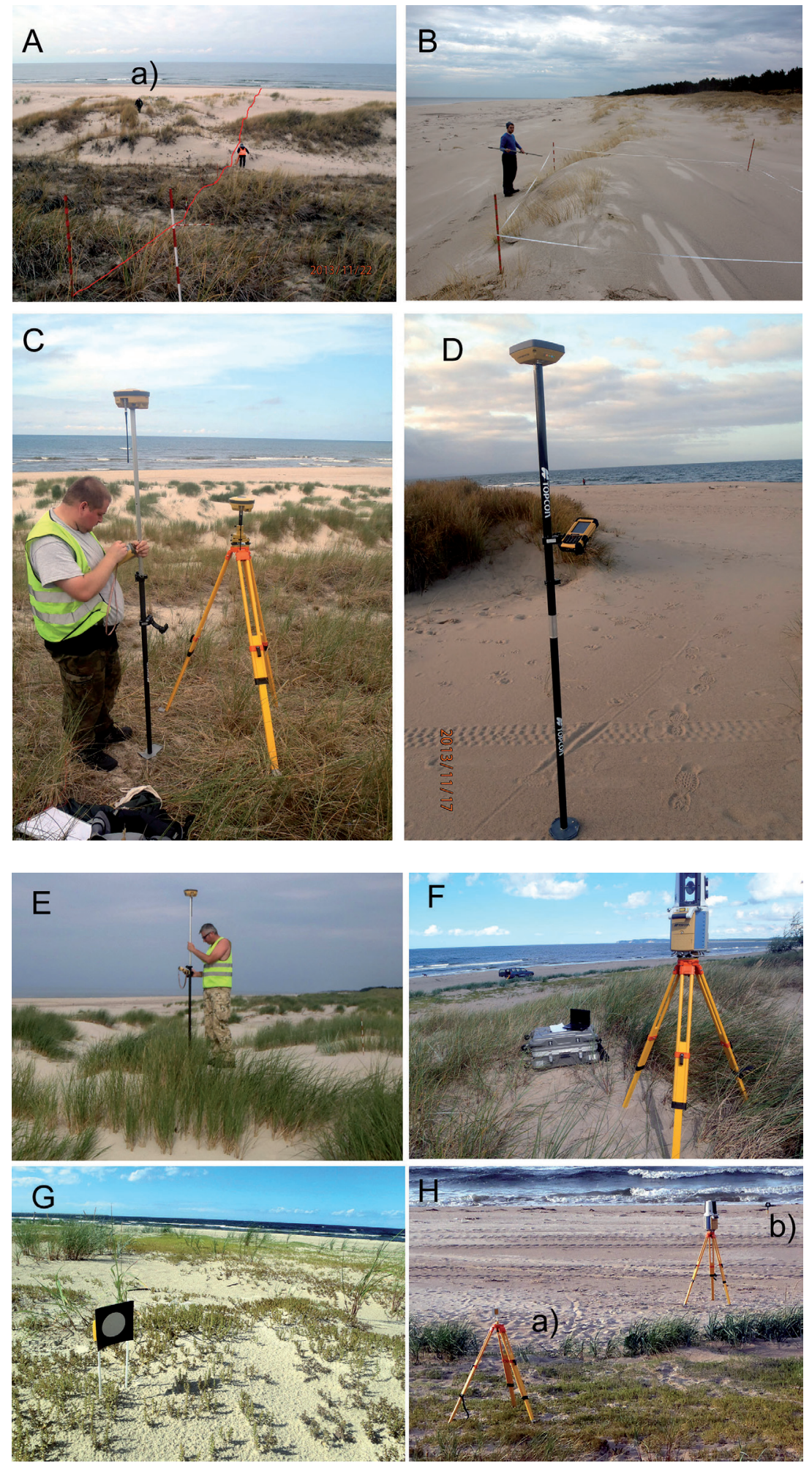

Ryc. 4. Przykłady stosowanych w terenie metod pomiaru rzeźby

A - wytyczanie profilu poprzecznego wraz z lokalizacją niwelatora (a), B - wyznaczone poletko do pomiarów powierzchniowych 5x5m, C - lokalizacja bazy i uruchamianie urządzenia RTK dGPS, D - mobilne urządzenie HiPer SR, E - pomiary rzeźb wydmy przy użyciu HiPer II, F - skaner naziemny GSL-1500 z podręcznym komputerem do sprawdzania poprawności zebranych danych, $\mathrm{G}$ - tarczka - punkt węzłowy do dowiązywania skanów, H - skaner naziemny zlokalizowany pomiędzy tarczkami na wydmie (a) i plaży (b)

Fig. 4. The examples of surveying methods used during field investigation

A - transverse profile across dunes with the leveler location (a), B - designated plot for surface measurements $5 \times 5 \mathrm{~m}, \mathrm{C}$ - the location of the database and run of the RTK dGPS rover device, D - mobile device HiPer SR, E - dunes measurements using HiPer II rover, F - terrestrial scanner GSL-1500 with handheld PC to validate the collected data, G - shield - a nodal point for tying scans, $\mathrm{H}$ - terrestrial scanner located between nodal points on a sand dune (a) and the beach (b) 


\section{Pomiary przy użyciu RTK GPS oraz dGPS}

Badania takie umożliwiają uzyskanie bardzo dokładnego odzwierciedlenia ukształtowania terenu oraz jego zmian (Pardo-Pascual i in. 2005, Harley i in. 2011, Jeong-Min i in. 2013). Dokładność uzyskanych wyników zawsze zależy od staranności badacza dokonującego pomiaru. Badania te na wydmach nadmorskich w Polsce realizowane są w projekcie FoMoBi od 2012 r. (Łabuz, Osóch 2013). Do badań tych wyznaczono: dwa obszary po obu stronach ujścia Wisły (Jantar oraz Sobieszewo), trzy na Mierzei Łebskiej (rejon Łąckiej wydmy oraz Czołpińskiej wydmy) oraz dwa na Mierzei Bramy Świny.

Dane zbierano przy użyciu zestawu dGPS RTK (Differential Global Positioning system) marki Topcon, operującego wielokanałowo w ramach odbioru i przesyłu danych. Zestaw składa się z dwóch odbiorników marki HiPer II (odbiornik bazowy oraz odbiornik ruchomy) i kontrolera FC-250 pracującego pod kontrolą systemu Windows Mobile (ryc. 4C). Od 2013 r. w badaniach stosowany jest samodzielny odbiornik RTK GPS (tzw. rover) marki Hiper SR firmy Topcon (ryc. 4D). Zestaw składa się jedynie z kontrolera FC-336 oraz odbiornika łączącego się z oraz przez kartę telefoniczną SIM z naziemną bazą poprawek sieci ASG EUPOS lub sieci TPI Net PRO.

Zainstalowane oprogramowanie w obu urządzeniach TopSurv 8, jest kompleksowym rozwiązaniem do pozyskiwania danych cyfrowych. Pozwala kontrolować wszystkie funkcje w odbiornikach GPS, prowadzić pomiary, a następnie przesłać dane do komputera stacjonarnego.

Ze względu na brak odpowiedniej osnowy geodezyjnej w miejscu prowadzenia pomiarów oraz brak stałego sygnału GSM, założono własną osnowę pomiarową, opartą o trzy punkty (wg wytycznych badań topograficznych), dla których dokonano statycznych pomiarów GPS. Punkty te zlokalizowano po obrysie trójkąta, tak by po wyrównaniu sieci uzyskać jak najmniejszy błąd średniego położenia punktu bazowego. Te punkty bazowe, po precyzyjnym wyrównaniu sieci dostępu mogą być wyznaczane $\mathrm{z}$ dokładnością $3 \mathrm{~mm}$ położenia geograficznego na współrzędnych $x$ i $y$. Z kolei współrzędne wysokościowe $h$, punktów sieci bazowej posiadały wysokość określoną z dokładnością do $5 \mathrm{~mm}$. Z tego wynika, że rzeczywista dokładność pomiaru wysokości wynosiła $0,5 \mathrm{~cm}$ a odległości $0,3 \mathrm{~cm}$. Są to bardzo dokładne dane, jednak ich pozyskanie zajmuje dużo czasu. Uzyskiwanie rzeczywistej wysokości każdych trzech punktów bazowych zajmowało do 9 godzin pracy w terenie. Precyzyjne wyznaczenie punktów bazowych pozwoliło na zapewnienie wymaganej dokładności przy realizacji dalszych zadań pomiarowych. Po tym etapie możliwe było rozpoczęcie pomiarów właściwych - wysokości rzeźby terenu.

Rejestracja parametrów morfologicznych wydm oraz plaży odbywała się w oparciu o dwa z trzech punktów bazowych, przy czym zachowany był wymóg kontroli położenia sąsiednich punktów bazowych. Przed każdym pomiarem bazę nadającą poprawki ustawiano na jednym trzech punktów bazowych. Wprowadzano wszystkie obliczone parametry stanowiska bazowego oraz średnią z trzykrotnie mierzonej wysokości urządzenia nad poziomem gruntu, po czym dokonywano startu bazy. W ramach kontroli z pierwszego ustawienia bazy mierzono położenie pozostałych dwóch punktów sieci. Następnie ustawiano odbiornik bazowy na kolejnym punkcie węzłowym sieci i dokonywano pomiaru punktu, na którym baza stała w pierwszym położeniu. Po tak przeprowadzanych zabiegach przygotowawczych przystępowano do pomiarów na wyznaczonym wcześniej poligonie badawczym. Od tego momentu baza transmitowała na bieżąco do odbiornika ruchomego poprawki, umożliwiające precyzyjne określenie jego położenia w przestrzeni. Odbiornik ten był wykorzystywany w pomiarach przestrzennych.

Przykładowy poligon badawczy obejmował obszar przebiegający wzdłuż brzegu o szerokości 50 (60) metrów. Pomiar wykonywany był od utrwalonych wałów wydmowych (piaszczyste podłoże pokryte mchami|), poprzez rejon występowania wydm embrionalnych oraz plażę do linii wody. Szerokość każdego obszaru uzależniona była od szerokości pasa ruchomych wydm przednich oraz szerokości plaży (minimalnie 100 m, maksymalnie 200 $\mathrm{m})$. Przed przystąpieniem do pomiarów wyznaczano granice każdego poligonu za pomocą tyczek. W celu uzyskania orientacji w terenie, w poligonie co 10 lub $20 \mathrm{~m}$ rozstawiano tyczki: na grzbiecie wydmy przedniej, u podnóża wydm embrionalnych oraz na wale brzegowym. Podczas pomiarów nocnych stosowano światło sztuczne sygnalizujące granice obszaru pomiarów oraz wyznaczonych na samych wydmach kwadratów o powierzchni 20x20 m. Rozwiązanie to zastosowano celem uniknięcia pomyłek w orientacji terenowej, która po zmierzchu jest utrudniona. Było to niezbędne w czasie prac terenowych realizowanych w okresie, gdy dzień jest krótszy; a same pomiary zajmują dużo czasu, że nie jest możliwe ich wykonanie podczas samego dnia.

Pomiary zawsze rozpoczynano od dokładnego wyznaczenia obwodu poligonu oraz linii poprzecznych, określonych przez dodatkowo rozstawione tyczki. Pomiar wysokości poszczególnych form w poligonie polegał na wykonaniu obrysu podstawy każdej formy oraz jej krawędzi grzbietowych (lub grzbietu jeżeli był wąski). Mobilny rejestrator GPS ustawiany na powierzchni piasku lokalizowano tak, by wiarygodnie odzwierciedlić układ form rzeźby (ryc. 4E). Liczba punktów na metr kwadratowy powierzchni uzależniona była od zróżnicowania wysokości. Przy dużych różnicach odczyt wykonywano w odległości co kilka centymetrów. Na plaży odczyt wykonywano w odległości co 4-5 m od kolejnych punktów. $Z$ tego powodu pomierzenie powierzchni o wymiarach 50 na 100 m zajmowało od 12 do 15 godzin pracy ciągłej. Na takiej powierzchni rejestrowano od 2000 do 3000 punktów. Przekracza to możliwości wykonania pomiarów w ciągu operacji słońca, a ich przerywanie niweczy możliwość uzyskania wyników z większej powierzchni. Badania zmian wysokości uzupełniono o oznaczenie rozmieszczenia roślinności. Każdy z pomierzonych punktów, służący 


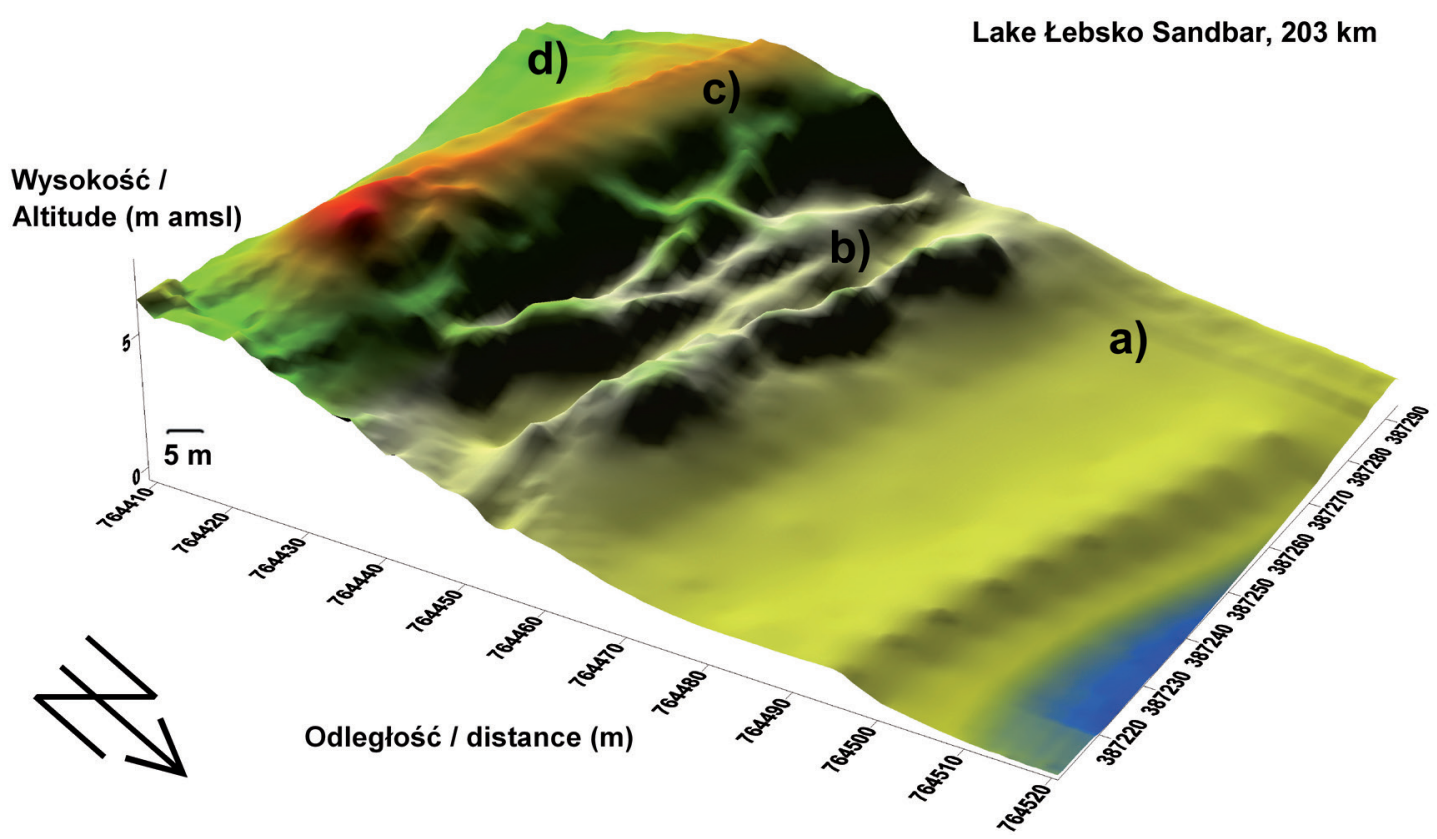

Altitude ( $\mathrm{m}$ amsl)

Ryc. 5. Ukształtowanie wydm na podstawie CMW (DEM) uzyskane za pomocą urządzenia GPS RTK, wybrzeże wydmowe w rejonie wydmy Czołpińskiej (203 km wybrzeża)

$\mathrm{a}$ - plaża, b - wydma embrionalna, c - wydma przednia, d - rynna

Fig. 5. Dunes relief on the basis of DEM obtained using RTK GPS device, coastal dune in the area of Czołpińska dune (203 km of coastline)

$\mathrm{a}$ - beach, $\mathrm{b}$ - embryo dune, $\mathrm{c}$ - foredune, $\mathrm{d}$ - runnel

do konstrukcji cyfrowego modelu terenu posiadał średni błąd położenia nie większy $10 \mathrm{~mm}$ (współrzędna $x$ i $y$ ) oraz 15 mm (współrzędna $z$ ).

Konstruowanie cyfrowego modelu wysokościowego (CMW; ang. DEM - Digital Elevation Model) odbywało się w oprogramowaniu Surfer 8 firmy Goleden Software (ryc. 5). W konstrukcji modeli korzystano z licznych wytycznych wskazujących najlepsze logarytmy oprogramowania (Pardo-Pascual i in 2005). Obliczenia zmian wysokości z modeli wykonywano przy użyciu programów: WinKalk, MicroMap lub AutoCad Map 2011. Zmiany objętości obszaru przypadającego na daną wysokość nad poziom morza można obliczyć także w programie Surfer. Na podstawie tych danych przeprowadzono analizy cech morfometrycznych wydm nadmorskich oraz możliwe zmiany położenia krawędzi, podstawy lub grzbiecików form $w$ relacji do istniejącej topografii lub innych przeszkód terenu, w tym kęp roślin. Objętości osadu wydm zostały odniesione do poziomu podstawy wydmy (obrysu obwodu jej podstawy). Wynikami tych badań są: cyfrowe modele wysokościowe, mapy różnic oraz tabele różnic wysokości i zmian objętości form. W dalszych etapach prac dane są korelowane $\mathrm{z}$ rozmieszeniem roślinności i warunkami aerodynamicznymi.

\section{Powierzchniowe pomiary rzeźby skanerem TLS}

Metoda laserowego skaningu powierzchni w Polsce jest dopiero wdrażana (Pilecki 2012). Skaner umożliwia pomiary bez ingerencji badacza w rzeźbę terenu. Przy pomiarach innego typu obecność badacza może wpływać na mikro zmiany rzeźby terenu - np. przy metodzie GPS RTK (formy ruchomego podłoża mogą być rozdeptane). Skaner może być wykorzystany do pomiarów sezonowych zmian rzeźby wydm embrionalnych lub wydm przednich (Feagin i in. 2012, Montreuil i in. 2013).

Pomiar skanerem polega na emitowaniu przez urządzenie wiązki światła koherentnego, która odbija się od powierzchni obiektu i powraca do urządzenia (Pilecki 2012). Uzyskuje się dzięki temu informacje o położeniu obiektu względem urządzenia, o relacjach, mierzonych w kątach poziomych i pionowych. Na tej podstawie zostają obliczone szczegółowe współrzędne $x, y, z$, położenia obiektu względem miejsca położenia skanera. W pamięci urządzenia gromadzi się tzw. chmura punktów o znanych współrzędnych w przestrzeni. Na jej podstawie możliwe jest skonstruowanie rzeczywistego obrazu pomierzonego obiektu. Uzupełnieniem pomiarów są zdjęcia fotograficzne wykonywane przez skaner wokół rejonu badań. Umożliwiają one rzeczywiste odtworzenie barw obiektów oraz dodatkowe nałożenie na chmurę punktów w celu wiarygodnego odtworzenia rzeźby terenu. Błąd pomiaru lasera zależy od dokładności odczytu urządzenia i od jego typu, najczęściej jest mniejszy niż $3 \mathrm{~mm}$. Zasięg prac urządzenia zależy od jego parametrów technicznych. Przykładowo skaner Opti-tech potrafi dokonać pomiarów w odległości do 800 m od urządzenia. Skaner Faro nadaje się do pomiaru małych powierzchni i zlokalizowanych w bliskiej odległości, do $80 \mathrm{~m}$ zasięgu od urządzenia. Używany w badaniach skaner GLS 1500 firmy Topcon umożliwiał dokonanie pomiaru w zasięgu do $150 \mathrm{~m}$ od urządzenia (ryc. 4F). Testowano również skaner Skan- 


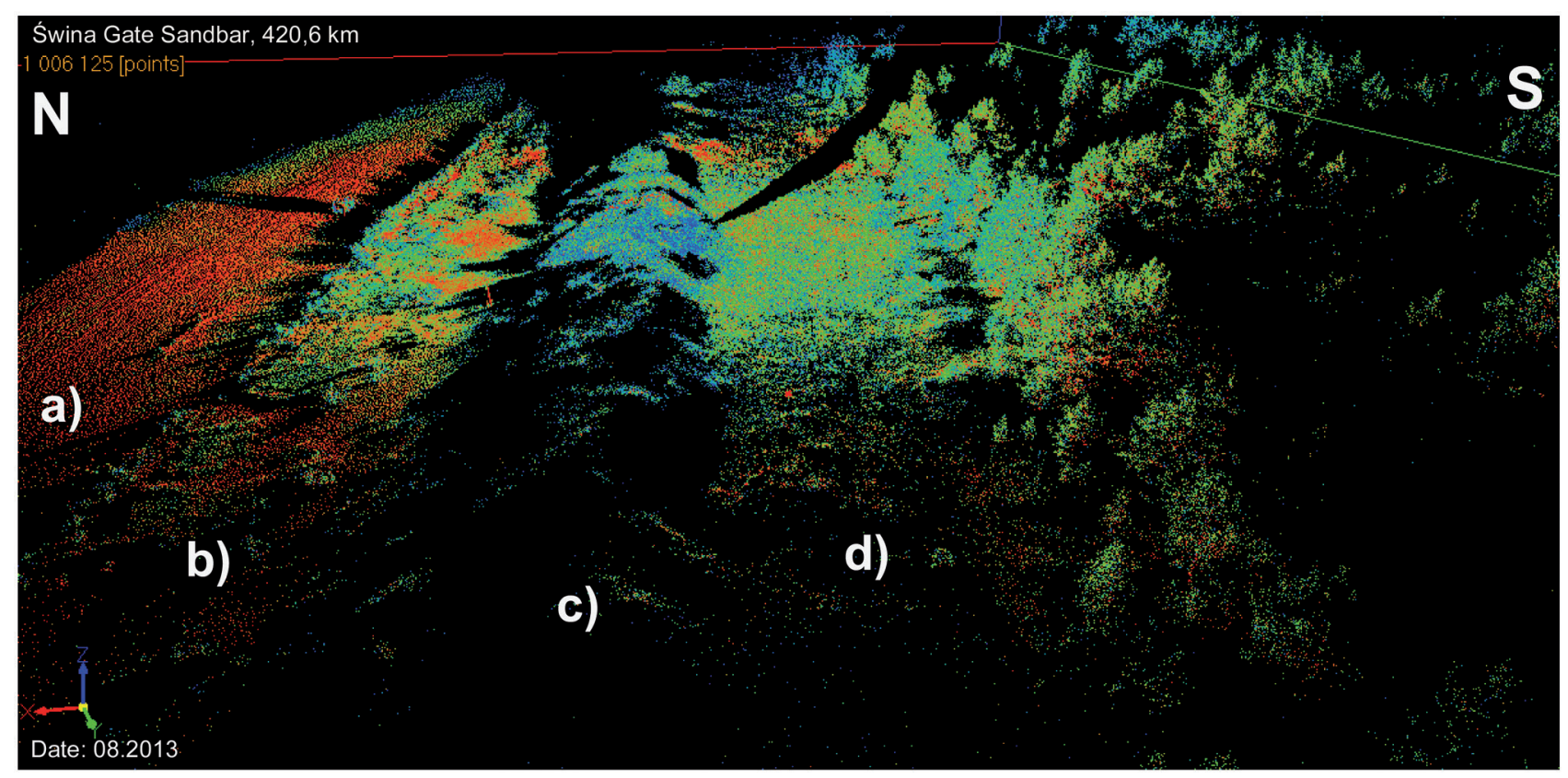

Ryc. 6. Ukształtowanie wydm uzyskane na podstawie naziemnego skanowania laserowego (TLS), wybrzeże wydmowe w rejonie Świnoujście-Przytór (420,6 km wybrzeża)

$\mathrm{a}$ - plaża, $\mathrm{b}$ - wydma embrionalna, $\mathrm{c}$ - wydma przednia, $\mathrm{d}$ - rynna

Fig. 6. Dunes relief obtained using terrestrial laser scanning (TLS), coastal dune in the area of Świnoujscie-Przytór (420.6 km of coastline)

$\mathrm{a}$ - beach, $\mathrm{b}$ - embryo dune, $\mathrm{c}$ - foredune, $\mathrm{d}$ - runnel

master firmy Leica, działający z podobną dokładnością jak urządzenie firmy Topcon (Labuz 2014d). W celu powiększenia obszaru badań należało przestawić urządzenie oraz zastosować repery mogące posłużyć do połączenia uzyskanych wyników z pojedynczych zestawów danych (tzw. chmura punktów) w jeden plik punktów.

Podczas pomiaru terenowego urządzenie ustawiane było w danym, konkretnym położeniu. Po jego uruchomieniu i zaprogramowaniu dokładności skanowania realizowano odczyty, zapisywane w pamięci podręcznej. W zależności od geometrii obiektu skanowanie należało wykonać z różnych stanowisk, celem uchwycenia całego kształtu formy. Wiązka lasera zatrzymuje się na eksponowanych stokach, tak więc stoki osłonięte muszą być zeskanowane z kolejnego ustawienia urządzenia. Przy obiektach takich ja podłużny wał wydmowy, wydma embrionalna, należy wybrać kilka lokalizacji urządzenia. W celu uchwycenia dłuższego odcinka rzeźby skaner można ustawiać wzdłuż formy, w odstępach umożliwiających dowiązanie zebranych chmur punktów w jeden obraz. W celu uzyskania odzwierciedlenia rzeźby terenu: rynny międzywydmowej, wału wydmy przedniej, plaży górnej pokrytej wydmami embrionalnymi oraz plaży dolnej, skaner ustawiano na jednej osi w trzech ustawieniach: na drugim wale wydmowym, na pierwszym wale wydmowym oraz na plaży górnej. Dystans ustawień zależny był od zasięgu skanowania oraz od założonej dokładności pomiaru. Na wydmie przedniej oraz plaży górnej rozdzielczość skanowania określano na 3-5 cm (1 punkt na 3-5 $\mathrm{cm}$ powierzchni). Skanowanie takie zajmowało od 1 do 1,5 godziny czasu. Na plaży dolnej testowano skanowanie z rozdzielczością do 5 i $10 \mathrm{~cm}$, co zajmowało od 30 do 40 minut. Obszar do skanowania był oznaczany w terenie za pomocą tyczek, na których lokalizowano tarczki o białym kolorze, łatwo rozpoznawalne przez badacza i wiązkę lasera, tak by uzyskać punkty węzłowe potrzebne przy przestawianiu skanera na nowe miejsce (ryc. 4G, 4H).

Badania przy użyciu skanera przeprowadzono trzykrotnie, latem 2013, 2014 i 2015 r. Miejsca, w których wykonano pomiary to Mierzeja Bramy Świny, mierzeja w okolicy Pobierowa oraz odcinki erozyjne wydmowe i klifowe zachodniego wybrzeża (klifowe - niezwiązane z niniejszą pracą). Wyniki tych badań to tzw. chmury punktów w przestrzeni lokalizowane względem punktów węzłowych. Celem ich lokalizacji geograficznej należy wykonać dodatkowe pomiary położenia skanera lub punktów węzłowych skanowanego obszaru. W odpowiednim oprogramowaniu dają wiarygodne odzwierciedlenie rzeźby terenu (ryc. 6). Godzinny pomiar daje od 1 do $1,5 \mathrm{mln}$ punktów o znanym względem urządzenia położeniu. Tak ogromne ilości danych wymagają wielu godzin opracowywania, którego rezultatem są liczbowe różnice wysokości, objętości i położenia form względem siebie.

\section{Zmienność wydm przednich uzyskana na podstawie badań}

Wydmy przednie zwiększają swoją wysokość i objętość najczęściej podczas wiosennej akumulacji osadu nawiewanego z plaży i stabilizowanego przez pionierską roślinność psammofilną - nazywaną wydmotwórczą (ma- 
rzec-czerwiec). W tym okresie wysokość wału wzrasta średnio o $2-5 \mathrm{~cm}$. Sumarycznie w okresie 2 lat maksymalny wzrost wysokości wydm wyniósł 0,65 m (ryc. 9). Podsumowanie wybranych parametrów morfologicznych i ich sezonową zmienność, uzyskanych różnymi metodami pomiarowymi zawiera tabela $\mathrm{nr} 3$.

Ustalono, że naturalnie powstająca wydma przednia jest nieregularnym wałem, pokrytym przez kopuły i obniżenia, o zróżnicowanym tempie wzrostu. Tempo to uzależnione jest od bilansu osadu plaży, rozmieszczenia pokrywy roślinnej i ekspozycji na kierunki najczęstszych wiatrów. Forma ta nie przyjmuje kształtu typowo rozpoznawalnego wału piasku, który najczęściej jest spotykany; i jest efektem prac antropogenicznych. Pas wydm przednich jest morfologicznie zróżnicowaną formą, cechującą się epizodami wzrostu i deflacji, a w warunkach ekstremalnych - abrazji morskiej.

Z badań wynika, że najdłuższe odcinki akumulacyjne występują na Mierzei Bramy Świny, Mierzei Gardnieńsko-Łebskiej oraz na Wyspie Sobieszewskiej. Na tych mierzejach tempo rozwoju wydm jest najszybsze. Dotyczy to nie całych mierzei, a odcinków o długości 3-5 km, wykazujących stałe tendencje akumulacyjne. Odcinki te zostały wymienione w innej publikacji (Łabuz i in 2013). Rocznie wysokość wydm przednich tych rejonów wzrasta o 10-15 cm. Największą akumulację osadu na wydmach, dochodzącą średnio do $0,5 \mathrm{~m}^{3} / \mathrm{m}^{2}$ zaobserwowano w środkowej części Mierzei Bramy Świny. W tym rejonie od 20 lat obserwowany jest szybki rozwój nowych wałów wydmowych (ryc. 6). Najmniej w okresie badań przyrastała wysokość i objętość osadu wydm przednich na Mierzei Wiślanej. Duże zmiany wysokości wydm przednich rejestrowano na Mierzei Łebskiej w rejonie Wydmy Łąckiej oraz Czołpińskiej.

Na plażach badanych odcinków występują wydmy embrionalne, które zwiększają swoje rozmiary tam, gdzie plaża posiada wysokość większą, niż napływ wody podczas spiętrzeń sztormowych (powyżej 3,2 m). Formy te wykazują dużą dynamikę w czasie. Okresowo są niszczone, a następnie odbudowywane. $\mathrm{W}$ miejscach występowania oraz rozrostu roślinności formy te stale wzrastają. Swoją wysokość i objętość najczęściej zwiększają w okresie wiosny (ryc. 8), co wynika z obecności roślinności hamującej transport eoliczny wymuszony przez silne wiatry wiejące o tej porze roku z kierunku zachodniego - wzdłuż plaży lub po skosie do wydmy.

W ciągu pół roku, średni wzrost ilości osadu w wydmie wynosi od 0,2 do $0,4 \mathrm{~m}^{3} \mathrm{~m}^{-2}$. Jest to ilość równoznaczna z dynamiką, rozumianą jako bezwzględne zmiany wysokości pomierzone w ciągu roku (ryc. 9). Analiza zmian wysokości średnich na podstawie pomiarów w poletkach wskazuje na stały wzrost plaży górnej i wydmy przedniej we wszystkich badanych obszarach wybrzeża.

Trend zmian wysokości wydm embrionalnych na plaży jak i na wydmie przedniej jest zbliżony we wszystkich badanych obszarach. Wielkość wzrostu tych form uwarunkowana jest przez rozmieszczenie roślinności i występowanie w danym sezonie wiatrów. Muszą to być wiatry o dużych prędkościach i odpowiednim kierunku do ekspozycji plaży i wydm. Ekspozycja brzegu wydmowego,

Tabela 2. Średnie godzinne wartości zmian wysokości wydm embrionalnych podczas zdarzenia ekstremalnego z 12.2013, huragan Xavier. Pomiary z odczytu 10-ciu reperów

Table 2. Average, hour hieght changes of the embryo dunes Turing extreme event, 12.2013, hurricane Xavier. Measure reading based on 10 piles

\begin{tabular}{|c|c|c|c|c|c|c|c|}
\hline Kolejny pomiar (Instalacja: 04.12, godz. 15.00)/Next measure & 1 & 2 & 3 & 4 & 5 & 6 & 7 \\
\hline Dzień/Day & 05.12 & 05.12 & 05.12 & 05.12 & 05.12 & 06.12 & 07.12 \\
\hline Godzina/Hour & 10.00 & 12.00 & 13.00 & 14.00 & 16.00 & 10.00 & 14.00 \\
\hline Średnia dobowa prędkość wiatru, pomiar anemometrem w terenie & 11,8 & 11,8 & 12,7 & 14,6 & 17,8 & 18,7 & 12,4 \\
\hline
\end{tabular}

Average wind velocity, measure on field $\left[\mathrm{m} \mathrm{s}^{-1}\right]$

\begin{tabular}{|c|c|c|c|c|c|c|c|c|c|c|}
\hline \multicolumn{4}{|c|}{ Parametry form/forms characteristics } & \multirow{2}{*}{\multicolumn{7}{|c|}{$\begin{array}{c}\text { Zmiany wysokości }\left[\mathrm{cm} \mathrm{h}^{-1}\right] \\
\text { Height changes }\left[\mathrm{cm} \mathrm{h}^{-1}\right]\end{array}$}} \\
\hline $\begin{array}{l}\text { Wysokość } \\
\text { Height }\end{array}$ & Wysokość względna & $\begin{array}{l}\text { Odleglość od podstawy } \\
\text { wydmy }\end{array}$ & $\begin{array}{l}\text { Gatunek roślin } \\
\text { Species }\end{array}$ & & & & & & & \\
\hline 2,20 & 0,25 & 13,0 & $\mathrm{H}$ & 0,42 & 0,50 & 1,80 & 2,20 & 2,35 & 1,41 & b.d. \\
\hline 2,25 & 0,30 & 14,5 & $\mathrm{H}$ & 0,45 & 0,45 & 2,60 & 1,70 & 1,35 & 1,50 & b.d. \\
\hline 2,40 & 0,25 & 12,2 & $\mathrm{H}$ & 0,37 & 1,00 & 0,50 & 3,10 & 3,05 & 1,39 & b.d. \\
\hline 2,47 & 0,35 & 12,0 & $\mathrm{H} / \mathrm{A}$ & 0,42 & 0,70 & 2,40 & 0,70 & 1,35 & 1,64 & 0,87 \\
\hline 2,50 & 0,35 & 11,0 & A & 0,47 & 0,70 & 3,00 & 2,00 & 0,75 & 1,53 & 1,12 \\
\hline 2,60 & 0,40 & 10,8 & A & 0,51 & 0,60 & 3,70 & 1,10 & 1,10 & 1,49 & 0,94 \\
\hline 2,70 & 0,40 & 11,0 & $\mathrm{E}$ & 0,54 & 0,30 & 3,00 & 1,80 & 1,15 & 1,44 & 0,96 \\
\hline 2,70 & 0,45 & 11,0 & $\mathrm{E}$ & 0,42 & 0,40 & 1,90 & 2,20 & 3,25 & 1,39 & 0,80 \\
\hline 2,80 & 0,50 & 12,0 & $\mathrm{E} / \mathrm{A}$ & 0,47 & 0,30 & 3,10 & 3,00 & 1,60 & 1,39 & 1,32 \\
\hline 2,90 & 0,60 & 10,0 & E/A & 0,45 & 0,65 & 3,00 & 3,90 & 1,45 & 1,24 & 1,12 \\
\hline Godzin & $\begin{array}{l}\text { miana wysokości uśr } \\
\text { Hour height chang }\end{array}$ & $\begin{array}{l}\text { dniona dla } 10 \text { punktów po } \\
\text { s, average for } 10 \text { points }\end{array}$ & miarowych & 0,45 & 0,56 & 2,50 & 2,17 & 1,74 & 1,44 & 1,02 \\
\hline
\end{tabular}

*- rośliny i ich wysokość (plants): H - honkenia piaskowa ( $\mathrm{H}=0,1 / 0,15 \mathrm{~m}), \mathrm{A}$ - piaskownica zwyczajna( $\mathrm{H}=0,35-0,5), \mathrm{E}$ - wydmuchrzyca piaskowa $(\mathrm{H}=0,5 \mathrm{~m})$. 
Tabela 3. Uśrednione wartości sezonowej dynamiki rzeźby wydm przednich (wiosna-jesień) na akumulacyjnych odcinkach polskiego wybrzeża za okres 2011-2013. Próba N=110, *-spiętrzenie sztormowe 01.2012, **-huragan Xavier, 12.2013

Table 3. Mean values of the seasonal dynamics of dunes sculpture Front (spring-autumn) on accumulative sections of the Polish coast for the period 2011-2013. Sample N =110, *- storm surge 01.2012,** - hurricane Xavier, 12.2013

\begin{tabular}{|c|c|c|c|c|c|c|}
\hline \multirow[t]{2}{*}{$\begin{array}{l}\text { Parametry rzeźby } \\
\text { Relief parameters }\end{array}$} & \multicolumn{2}{|c|}{$\begin{array}{l}\text { Wysokości } \\
\text { [m n.p.m.] } \\
\text { Altitude } \\
\text { [m a.s.1.] }\end{array}$} & \multicolumn{2}{|c|}{$\begin{array}{l}\text { Szerokości i odległości } \\
\text { Width and distances }[\mathrm{m}]\end{array}$} & \multicolumn{2}{|c|}{$\begin{array}{l}\text { Średnie objętości osadu } \\
\text { Average sand volume }\left[\mathrm{m}^{3}\right]\end{array}$} \\
\hline & $\begin{array}{c}\text { Średnie } \\
\text { Mean }\end{array}$ & $\begin{array}{c}\text { Maks. } \\
\text { Max }\end{array}$ & $\begin{array}{l}\text { Średnie } \\
\text { Mean }\end{array}$ & $\begin{array}{l}\text { Maks. } \\
\text { Max }\end{array}$ & {$\left[1 \mathrm{~m}^{-2}\right]$} & $\begin{array}{l}\text { Całkowite } \\
\text { Total }\end{array}$ \\
\hline $\begin{array}{l}\text { Wysokość i szerokość plaży } \\
\text { Beach height and width }\end{array}$ & 2,30 & 3,50 & 60 & 110 & - & - \\
\hline $\begin{array}{l}\text { Zmiany szerokości i wysokości plaży } \\
\text { Beach width and height changes }\end{array}$ & 0,40 & 2,0 & 15 & 55 & - & - \\
\hline $\begin{array}{l}\text { Dynamika osadu plaży górnej } \\
\text { Beach volume dynamic }\end{array}$ & - & - & - & - & 0,20 & 2,5 \\
\hline $\begin{array}{l}\text { Wzrost wysokości plaży górnej } \\
\text { Upper beach height growth }\end{array}$ & 0,25 & 0,60 & - & - & - & - \\
\hline $\begin{array}{l}\text { Wzrost wydmy embrionalnej } \\
\text { Embryo dune growth }\end{array}$ & 0,35 & 0,60 & - & - & - & - \\
\hline $\begin{array}{l}\text { Wysokość i szerokość wydm embrionalnych } \\
\text { Height and width of the embryo dune }\end{array}$ & 0,30 & 0,80 & 1,5 & 6,0 & - & - \\
\hline $\begin{array}{l}\text { Wysokość wydmy przedniej i szerokość, u podstawy } \\
\text { Height and width of foredune }\end{array}$ & 6,50 & 9,00 & 20 & 35 & - & - \\
\hline $\begin{array}{l}\text { Wzrost wysokości i objętości osadu wydmy przedniej } \\
\text { Foredune material volume growth }\end{array}$ & 0,25 & 0,75 & - & - & 0,12 & 1,5 \\
\hline $\begin{array}{l}\text { Dynamika objętości osadu wydmy przedniej } \\
\text { Foredune material volume dynamics }\end{array}$ & - & - & - & - & 0,25 & 2,0 \\
\hline $\begin{array}{l}\text { Erozja sztormowa, cofnięcie podstawy i zmiany objętości } \\
\text { osadu } \\
\text { Storm surge erosion, retreat and volume loss }\end{array}$ & - & - & $-0,75^{*}$ & $\begin{array}{c}-3,0^{*} \\
\text { (maks. }-9,0)\end{array}$ & $-0,16^{*}$ & $-1,4^{*}$ \\
\hline $\begin{array}{l}\text { Akumulacja eoliczna w rynnie za wydmą przednią } \\
\text { Aeolian accumulation behind foredune }\end{array}$ & - & - & - & - & 0,001 & $0,005^{* *}$ \\
\hline $\begin{array}{l}\text { Wysokość napływu wody podczas spiętrzenia sztormowego } \\
600 \mathrm{~cm} \\
\text { Water runup during storm surge }+1 \mathrm{~m} \text { a.s.l. }\end{array}$ & 2,50 & 3,50 & - & - & - & - \\
\hline
\end{tabular}

to jest kierunek na najczęściej występujące wiatry jest więc czynnikiem decydującym o wielkości zmian rzeźby wydm przednich.

W okresie wystąpienia wiatrów z prędkością przekraczającą $18 \mathrm{~m} \mathrm{~s}^{-1}$, w ciągu jednego dnia na wydmie przybywa warstwa osadu o miąższości od 0,1 do $0,15 \mathrm{~cm}$ (huragan Xavier, grudzień 2013). Jest to wartość porównywalna $\mathrm{z}$ rocznym przyrostem $\mathrm{w}$ okresach pozbawionych zdarzeń ekstremalnych (porównanie tabela 2 i 3 oraz ryc 8B i 9). W trakcie takiego zjawiska akumulację osadu obserwowano także na ustabilizowanym już zapleczu wydmy przedniej. Zmiany wysokości w rynnie międzywydmowej, za wałem wydmy przedniej były nieznaczne, około 0,5 - 1 $\mathrm{cm}$, i tylko w porze jesienno-zimowej. Były one powodowane najczęściej przez wiatry o bardzo dużej prędkości wiejące w okresie zimowym od strony morza. Podczas zdarzenia ekstremalnego, któremu towarzyszy intensywny opad deszczu akumulacja nie następuje (huragan Aleksandra, grudzień 2014). Na mokrym podłożu piaszczystym procesy eoliczne mają ograniczone oddziaływanie.

Na odcinkach brzegu, gdzie plaża jest niższa niż 2,5 m erozja sztormowa sięga podnóża wału. Średnie cofniecie podstawy wydmy dochodzi do $-0,75 \mathrm{~m}$. Ilość osadu roz- mywanego przez wodę osiąga średnio $-0,16 \mathrm{~m}^{3}$ na $1 \mathrm{~m}^{2}$ powierzchni całego wału. Po okresie erozji sztormowej, wiosną zachodzi powolna odbudowa podciętych stoków. Odbudowa ta trwa co najmniej 2 lata, ponieważ akumulacja roczna u podnóża wału (w sezonie wiosennym) osiąga około 1/3 ilości osadu rozmytego przez wodę.

W całym okresie badawczym 2010-2014 zmiany wysokości na plaży były większe niż na wydmie przedniej. Większy dodatni bilans osadu wystąpił na wydmie z powodu zatrzymywania akumulowanego osadu przez gęsto porastającą roślinność. W rejonach, gdzie na plaży górnej występowała (i nadal jest obecna) roślinność wzrost wydmy był mniejszy. Jest to skutek hamowania transportu eolicznego na wał wydmy i odkładania osadu pośród roślin na plaży górnej. W ten sposób powstawały wydmy embrionalne (por. ryc. 7).

Zarejestrowana w okresie badań dynamika rzeźby eolicznej powodowana była przede wszystkim wpływem wiatrów o dużych prędkościach, wiejących z sektora odmorskiego. Ekspozycja brzegu na kierunki wiatru była również czynnikiem morfotwórczym, który okazał się ważnym przy rozwoju wydm przednich. Najszybciej rozwijają się wydmy na odcinkach wybrzeża o ekspozycji 
na wiatry zachodnie. Wiatry te dominują w ciągu roku, co wykazano w wielu publikacjach. Trzecim czynnikiem decydującym o tempie akumulacji i o lokalnej zmienności rzeźby wydm było rozmieszczenie roślinności. Za każdym razem dodatnie zmiany wysokości były najczęściej związane z obecnością roślinności. Roślinność występująca na plaży górnej zatrzymywała osad trwale lub okresowo, do czasu wystapienia wiatrów o dużych i bardzo dużych prędkościach powodujących rozwiewanie. Graniczna prędkość wiatru powodująca rozwiewanie form eolicznych pokrytych trawami wynosi min. $8 \mathrm{~m} / \mathrm{s}$. Roślinność na wydmach powodowała akumulację osadu, czyli wzrost wysokości form. Sumarycznie, najbardziej trwała akumulacja rozumiana jako przyrost ilości osadu zachodziła na wydmie przedniej pokrytej trawami w 60$80 \%$. Pomierzone zmiany krótkookresowe wydm przednich wykazują trwałe tendencje akumulacyjne polskiego wybrzeża w badanych rejonach. Coroczny przyrost wysokości wydm i objętości osadu je budującego pozwala wskazać okres, w przeciągu którego powstanie nowy wał wydmowy, o wysokości powyżej $4 \mathrm{~m}$ npm. Na Mierzei Bramy Świny jest to czas 3-4 lata. Na Mierzei Łebskiej 4-6 lat, przy ujściu przekopu Wisły 3-6 lat po stronie zachodniej i 4-8 lat po stronie wschodniej. Na pozostałych odcinkach akumulacyjnych rozwój nowego wału może wynosić 10-15 lat. Odbudowa wydm po spiętrzeniach

Wzrost wydmy embrionalnej/ embryo dune growth

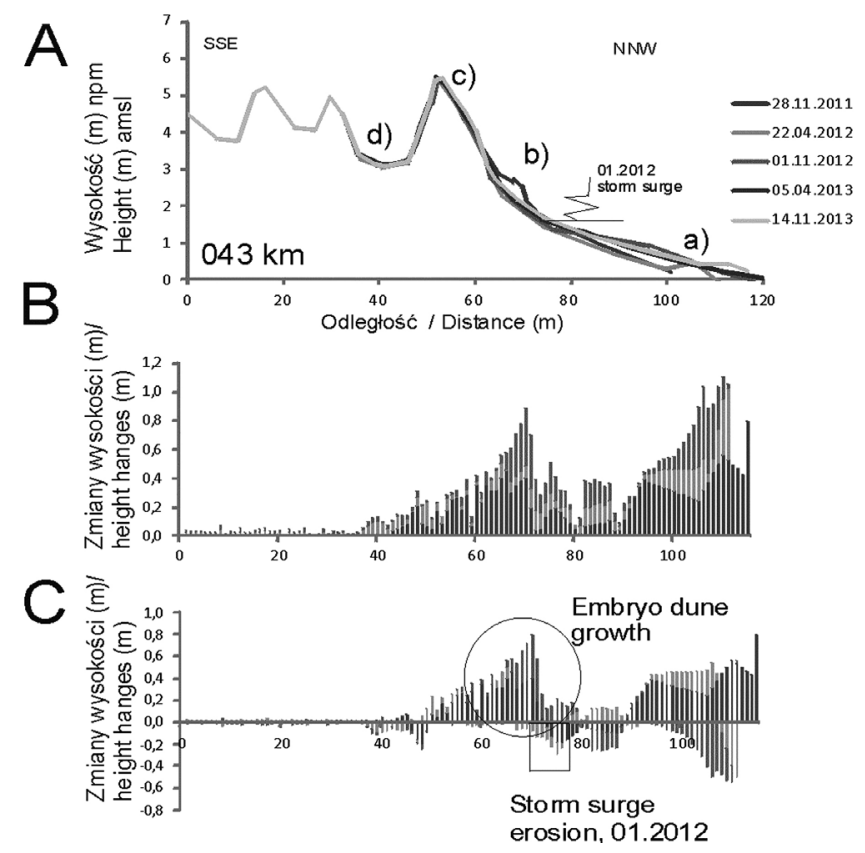

sztormowych zajmuje od 2 do 4 lat, o ile proces nie zostanie przerwany przez kolejne fazy erozji sztormowej.

\section{Wynikowa ocena stosowanych metod}

Zebranie danych terenowych pokazujących krótkookresowe zmiany rzeźby wydm nadmorskich można uzyskać za pomocą różnorodnych metod badawczych stosowanych $\mathrm{w}$ różnych skalach przestrzennych. Badania te są czasochłonne, jednak koszta ich są mniejsze niż współcześnie stosowane analizy ze zdjęć lotniczych, satelitarnych i skaningu powietrznego LiDAR. Ponadto dają bardziej szczegółowe i dokładniejsze wyniki dla małych obszarów. Prezentowane wyniki opracowano dla różnych, omówionych technik, na różnych obszarach wydmowych polskiego wybrzeża. Są to dane reprezentatywne z mierzei: Wiślanej, Helskiej, Łebskiej, Karwieńskiej, Kaszubskiej oraz Bramy Świny.

Punktowe pomiary rzeźby wydm nadmorskich należy stosować do potrzeb zebrania informacji o ekstremalnych zdarzeniach morfotwórczych lub okazjonalnych, krótkookresowych zmianach. Pomiary te informują o względnych zmianach wysokości form rzeźby terenu charakterystycznych dla zjawiska lub krótkiego okresu. Jeżeli punkty pomiarów są uprzednio dowiązane do sieci

\section{Wzrost wydmy przedniej/} foredune growth
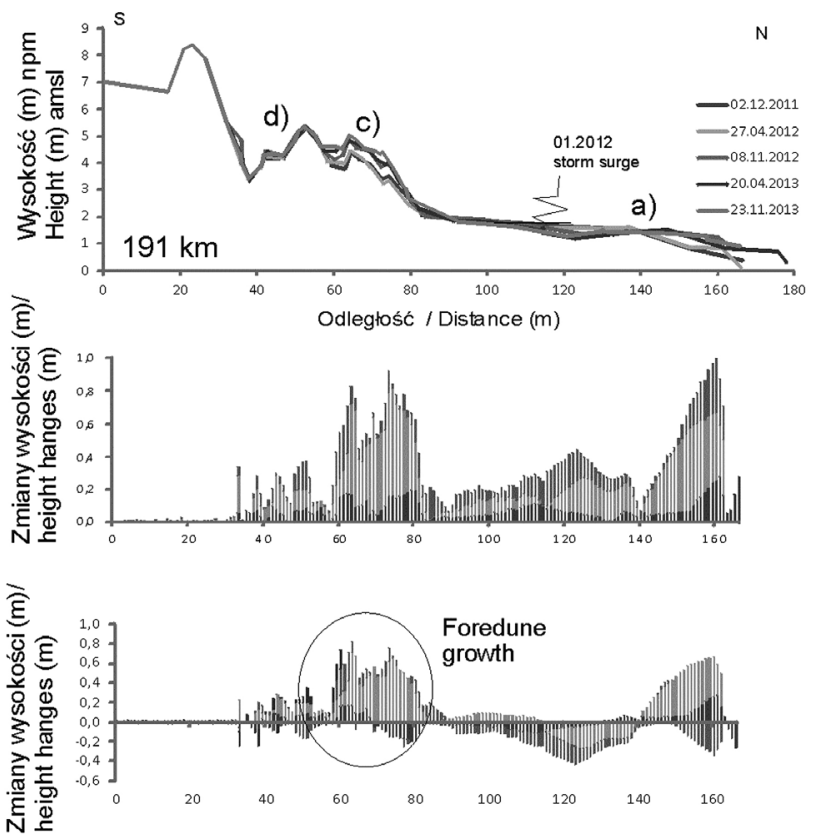

Ryc. 7. Przykład dynamiki rozwoju wydm przednich na profilach poprzecznych za okres 2 lat (2011-2013): wzrost wydmy embrionalnej lub wydmy przedniej A -warstwa dynamiczna na profilach: przyrost wysokości wydm obejmuje grzbiet, stok dowietrzny wydmy przedniej oraz plażę górną, B - dynamika wysokości: 1-3 m, C - bilans zmian wysokości: 0,6-2 m, a - plaża, b-wydma embrionalna, c - wydma przednia, d - rynna

Fig. 7. Example of dynamics of foredunes development of based on cross-section profiles for 2 years period (2011-2013): embryo dune or foredune growth

A - dynamic layer: the sand increase on dunes occurs on the ridge, on its wind slope and on upper beach, B - the height dynamics: 1-3 m, C - the balance of height changes: $0.6-2 \mathrm{~m}, \mathrm{a}$ - beach, $\mathrm{b}$ - embryo dune, $\mathrm{c}-$ foredune, $\mathrm{d}$ - runnel 
A

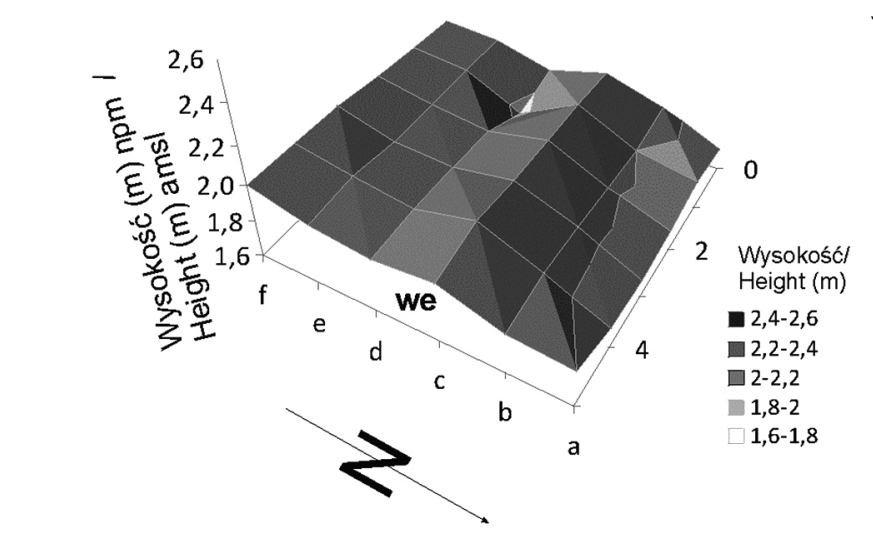

B

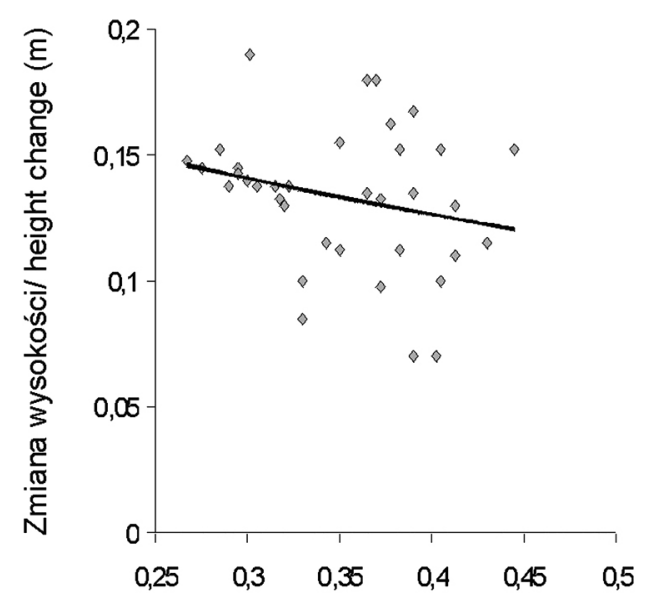

Dynamika podłoża/ surface dynamics $(\mathrm{m})$

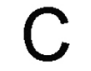

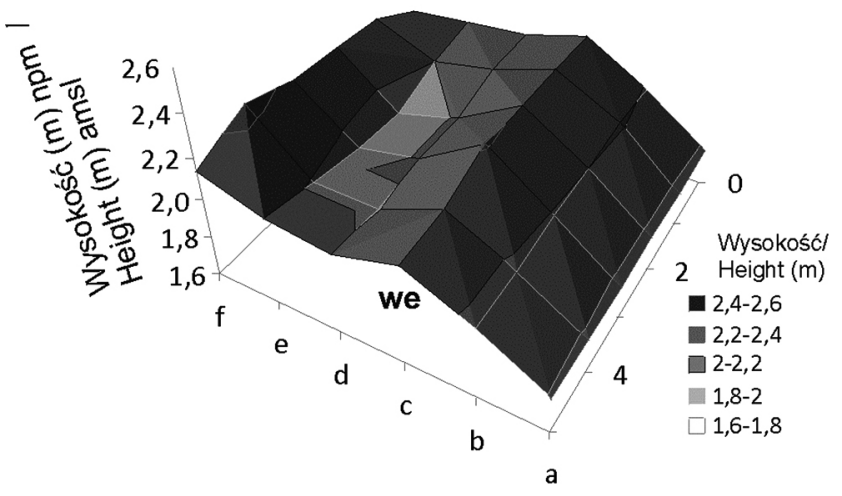

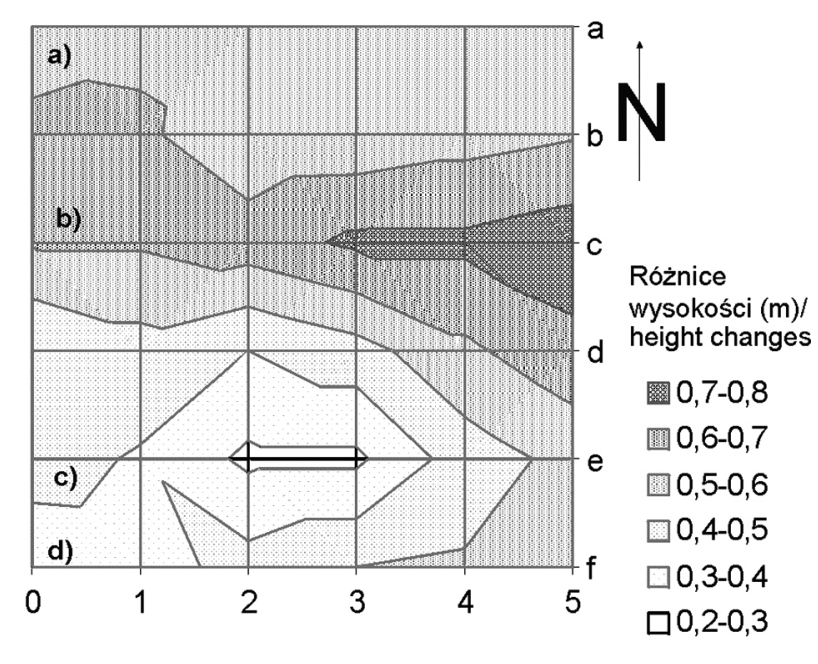

10.12.2014

Erozja: sztorm 10.2009 storm erosion

$-10$

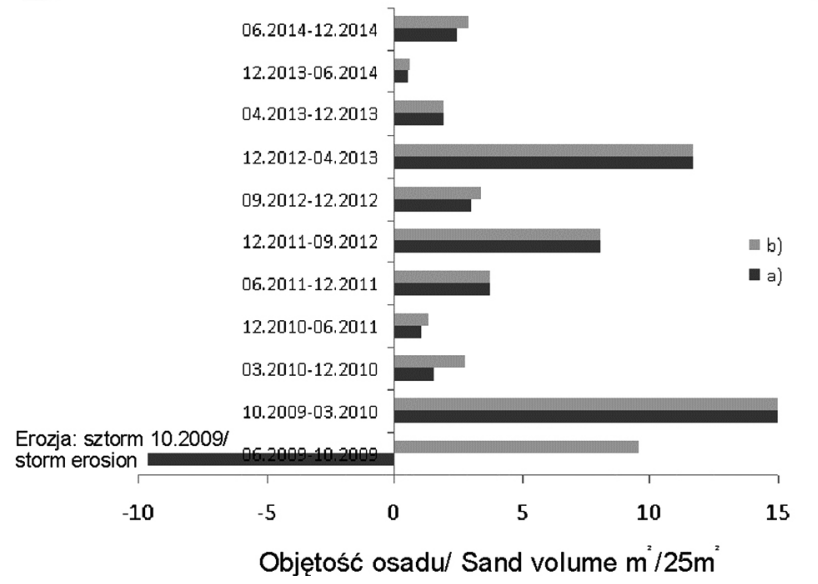

D

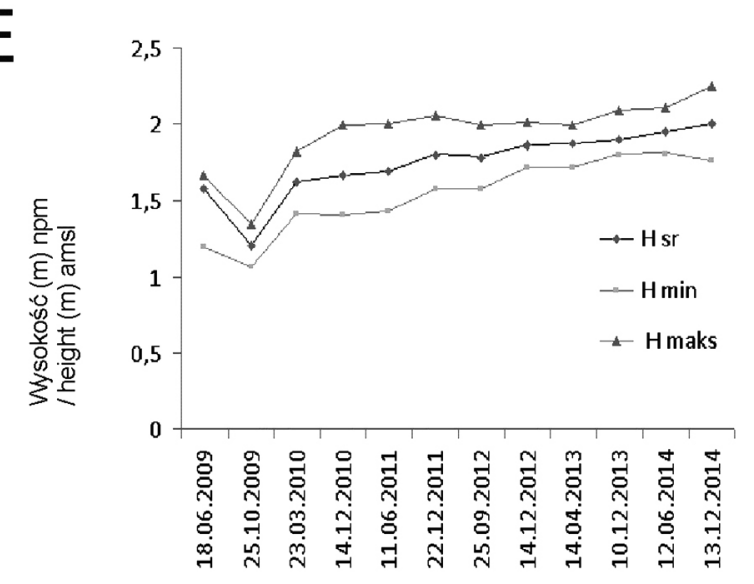

Ryc. 8. Zmiany rzeźby terenu w obrębie wydmy embrionalnej na przykładowym poletku o wymiarach 5x5 m (06.2009-12.2014)

A - morfologia i wysokość (m n.p.m.) w pierwszym i ostatnim okresie pomiarów, B - relacje zmian wysokości od dynamiki podłoża w ciągu roku (średnia za okres 5 lat), C - powierzchniowe zmiany wysokości za okres 5 lat, D - zmiany objętości osadu w kolejnych okresach: a) dynamika, b) bilans, E - wzrost średnich wysokości, we - wydma embrionalna

Fig. 8. The relief changes of the embryo dune in surface plot, size: $5 \times 5 \mathrm{~m}(06.2009-12.2014)$

A - morphology and height (m a.s.1.), B - relationship of height change and surface dynamics per year (5 years), C - surface height changes for 5 years, D - changes in the sand volume: a) dynamic, b ) balance, E - average growth of height in the plot, we - embryo dune 
geodezyjnej mogą być elementem monitoringu i prognoz zmiany rzeźby.

Pomiary liniowe umożliwiają interpretację zmian form rzeźby zarówno w krótkiej skali czasowej jak i w dłuższym okresie. Warunkiem ich stosowania jest dokładne wyznaczanie azymutu, wzdłuż którego dokonywany jest pomiar. Dane można wykorzystać do ukazania zmian morfologii, dynamiki rozwoju poszczególnych form oraz ukazania relacji zmian form sąsiadujących ze sobą (ryc. 7). Dane te są uzyskiwane w szybki sposób i są reprezentatywne do odcinków sąsiednich, w których zachodzą podobne zmiany w morfologii terenu.

Badania zmian rzeźby na powierzchni odzwierciedlają relacje wzajemne miejsc $\mathrm{z}$ uwzględnieniem obiektów, które na zmiany te wpływają. Dotyczy to zarówno uwarunkowań topograficznych terenu jak i rozmieszczenia roślinności. Pomiarem takim należy objąć całą formę terenu, tak by uchwycić jej zmienność w czasie i przestrzeni. Uzyskane wyniki mogą służyć do obliczenia różnych wskaźników zmian wysokości względnej i bezwzględnej, wartości dynamiki oraz tempa wzrostu form. Mogą posłużyć do wyznaczenia objętości osadu, który formę buduje oraz jego ilości podlegającej zmianom w każdym z założonych okresów pomiarowych (ryc. 8).

Większe powierzchnie poddane badaniom należy ograniczyć do minimum, determinowanego możliwościami czasowymi pomiaru oraz możliwościami posiadanego sprzętu badawczego. Wyniki ukształtowania terenu z większych powierzchni pozwalają objąć pomiarem całą formę, np. rynnę deflacyjną, kopułę lub grzbiet akumulacyjny oraz pas pola inicjalnej wydmy przedniej, pokrytego formami wydm embrionalnych (ryc. 5, 6). Rodzaj zastosowanych narzędzi w tych pomiarach daje zróżnicowana dokładność wyników. Należy tu mówić o modelach uzyskanych z pomiarów punktowych danej powierzchni lub o rzeczywistym odzwierciedleniu ukształtowania danej powierzchni.

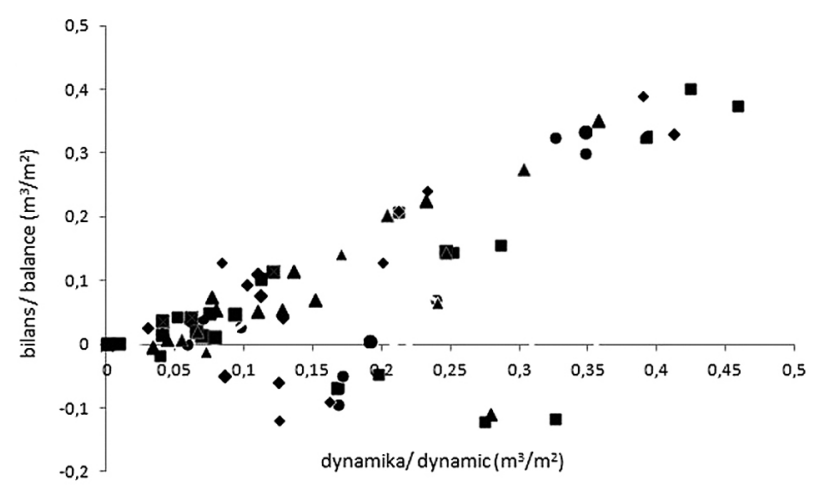

Ryc. 9. Sezonowa dynamik a wydm przednich środkowego i wschodniego wybrzeża Polski na odcinkach akumulacyjnych w latach 2011-2013 (wielkość zmian: sezony wiosnajesień)

Fig. 9. Seasonal dynamics of the foredunes dunes on east and middle Polish accumulative coast in 2011-2013 (changes rate: seasonal spring-autumn)

\section{Podsumowanie}

Skala zastosowanych metod, ilość wybranych do badań obszarów oraz różnorodność przestrzenna wyników są miarodajnym wskaźnikiem dynamiki akumulacyjnych odcinków mierzejowo-wydmowych polskiego wybrzeża. Ponadto omówione metody zostały przetestowane w różnych warunkach orograficznych, pokrycia roślinnością oraz pogodowych. Nie ma jednej metody, którą można zastosować do pomiarów morfologicznych dynamicznego podłoża wydm, zwłaszcza tych w strefie nadmorskiej. Metody muszą być dostosowane do celów badań. Ich wykorzystanie może być ograniczone przez szereg czynników ekonomicznych, czasowych oraz klimatycznych. W związku z tym należy zadać sobie pytanie jakie badania są istotne dla osoby chcącej analizować zmiany morfologiczne wybrzeża. Zakłada się, że rodzaj metod powinien być dostosowany do skali przestrzennej zmian lub skali czasowej oczekiwanych wyników. Nie ulega wątpliwości, że takie pomiary muszą być uprzednio przetestowane względem ukształtowania danej powierzchni.

$\mathrm{Z}$ przedstawionej pracy wynika, że programowanie takich badań nie należy do prostych i musi być poparte wiedzą z literatury przedmiotu odnośnie warunków stosowania urządzeń, ale również specyfiki danego obszaru. Uprzednia znajomość topografii i dynamiki obszaru jest niezbędna do formułowania założeń badań terenowych.

\section{Podziękowania}

Prezentowane wyniki są częścią prac realizowanych w projekcie NCBiR Rozmieszczenie i morfodynamika środowiska wydm przednich i fluktuacje roślinności bioróżnorodne siedlisko polskiego wybrzeża realizowanego w okresie 2011-2014.

\section{Literatura}

Andrade F., Ferreira M. A., 2006. A simple method of measuring beach profiles. Journal of Coastal Research 22(4): 995-999.

Bird E., 2002. Coastal Gomorphology. An introduction. John Wiley \& Sons, LTD, Chichester: 1-322.

Borówka M., 1979. Przebieg procesów deflacji i akumulacji na powierzchni nadbrzeżnych wałów wydmowych. Badania Fizjograficzne nad Polską Zachodnią, Geografia Fizyczna XXXIIA: 31-47.

Carter R.W.G., Wilson P., 1990. The geomorphological, ecological and pedological development of coastal foredunes at Magilligan Point, Northern Ireland. W: K.F.Nordstrom, N.P.Psuty, B.Carter (eds.), Coastal dunes. Form and processes. John Wiley \& Sons, Chichester:129-157.

Davidson-Arnott R.G.D., Law M.N., 1990. Seasonal patterns and controls on sediment supply to coastal foredunes, Long Point, Lake Erie. W: K.F.Nordstrom, N.P.Psuty, B.Carter (eds.), Coastal dunes. Form and processes. John Wiley \& Sons, Chichester: 177-200.

Davidson-Arnott R.G.D., Law M.N., 1996. Measurement and prediction of long-term sediment supply to coastal foredunes. Journal of Coastal Research 12: 654-663.

Feagin R.A., Williams A.M., Popescu S., Stukey J., Washington-Allen R.A., 2012. The use of terrestrial laser scanning (TLS) in dune ecosystems: the lessons learned. Journal of Coastal Research, http:// dx.doi.org/10.2112/JCOASTRES-D-11-002231. 
Harley M.D., Turner I.L., Short A.D., Ranasinghe R., 2011. Assessment and integration of conventional, RTK-GPS and image-derived beach survey methods for daily to decadal coastal monitoring. Coastal Engineering 58: 194-205.

Hesp P.A., 1984. Foredune formation in Southeast Australia. W: B.G.Thom (ed.), Coastal Geomorphology in Australia. Academic Press, Sydney: 69-97.

Hesp P.A., 2013. A 34 year record of foredune morphodynamics at Dark Point, NSW, Australia. W: D.C.Conley, G.Masselink, P.E.Russell, T.J. O'Hare (eds.), Proceedings $12^{\text {th }}$ International Coastal Symposium (Plymouth, England), Journal of Coastal Research, SI 65: 1295-1300.

Houser C., Hapke C., Hamilton S., 2008. Controls on coastal dune morphology, shoreline erosion and barrier island response to extreme storms. Geomorphology 100: 223-240.

Jeong-Min L., Jun-Yong P., Jin-Yong Ch., 2013. Evaluation of Sub-aerial Topographic Surveying Techniques Using Total Station and RTK-GPS for applications in Macro-tidal Sand Beach Environment., Proceedings 12th International Coastal Symposium (Plymouth, England), Journal of Coastal Research, SI 65: 535-540.

Łabuz T.A., 2007. Zapis współczesnych procesów eolicznych na Mierzei Bramy Świny w powierzchniowych poletkach badawczych. W: W.Florek (red.), Geologia i geomorfologia pobrzeża i południowego Bałtyku, Pomorska Akademia Pedagogiczna, Słupsk, 7: 161-176.

Łabuz T.A., 2009. The increase of the coastal dune area of the Swina Sandbar, West Polish coast. Zeitschrift der Deutschen Gesellschaft für Geowissenschaften 160(2): 123-135.

Łabuz T.A., 2011. Wpływ spiętrzeń sztormowych na przebudowę profilu wybrzeża wydmowego Mierzei Bramy Świny. Czasopismo Geograficzne 82(4): 351-371.

Łabuz T.A., 2013a. Polish coastal dunes - affecting factors and morphology. Landform Analysis, 22: 33-59.

Łabuz T.A., 2013b. Erosion reasons and rate caused by January 2012 storm surge on accumulative Polish dune coast. W: M.Reckermann, S.Köppen (eds), Conference proceedings $7^{\text {th }}$ Study Conference on BALTEX, Borgholm, Island of Öland, Sweden, 10-14 June 2013, International Baltex Secretariat, publication 53: 112-113

Łabuz T.A., 2014a. Foredune development over 10 years (2002-2013) in relation to beach height and storm surge influence along Polish Baltic Sea coast. W: A.N.Green, J.A.G.Cooper (eds.), Proceedings $13^{\text {th }}$ International Coastal Symposium, Durban, South Africa, Journal of Coastal Research, Special Issue 70: 743-748.

Łabuz T.A., 2014b. Erosion and its rate on an accumulative Polish dune coast: the effects of the January 2012 storm surge. Oceanologia 56(2): 307-326.

Łabuz T.A., 2014c. Metody analizy ilościowej dynamiki wydm nadmorskich w badaniach projektu FoMoBi. W: Streszczenia X Zjazdu Geomorfologów Polskich: Krajobrazy młodoglacjalne i ich morfogeneza, teraźniejszość i przyszłość, Uniwersytet Mikołaja Kopernika w Toruniu, SGP, 16-19.09.2014, Torun: 68.
Łabuz T.A., 2014d. Zastosowanie naziemnego skaningu laserowego w badaniach morfografii klifowych i wydmowych nadbrzeży morskich. W: S.Rudowski, P.Sitkiewicz, R.Wróblewski (red.), II Sympozjum Morskiej Geomorfologii. Poziom Morza, linia brzegowa, Instytut Morski w Gdańsku, 24.10.2014, Gdańsk: 38-39.

Łabuz T.A., 2015. Coastal dunes: Changes of their perception and environmental management. W: Ch.W.Finkl, Ch.Makowski (eds), Environmental management and governance. Advances in coastal and marine resources series. Coastal Research Library 8: 323-410.

Łabuz T.A., Osóch P., 2012. Dynamika rzeźby akumulacyjnego odcinka brzegu wydmowego w rejonie Dźwirzyna. W: W.Florek (red.), Geologia i geomorfologia pobrzeża i południowego Bałtyku, Pomorska Akademia Pedagogiczna, Stupsk, 9: 97-109.

Łabuz T.A., Osóch P., 2013. DTM models of coastal dune relief and dynamics as a tool for coast erosion and flooding prediction. W: $8^{\text {th }}$ IAG International Conference on Geomorphology, 27-31.09.2013, Paris, France, 2: 1134.

Łabuz T.A., Sławińska J., Osóch P., 2012. Issues of coastal dunes mapping in Poland. In: Book of Abstracts: IAG/AIG International Workshop on Objective Geomorphological Representation Models: Breaking through a New Geomorphological Mapping Frontier, University of Salerno, Cilento \& Vallo di Diano Geopark, Italy, 1519.10.2012: 85-87.

Łabuz T.A., Wochna-Bartnik S., Osóch P., Sławińska J., 2013. Projekt badawczy FoMoBi i jego znaczenie w rozpoznaniu współczesnej dynamiki i różnorodności biologicznej wydm przednich polskiego wybrzeża. W: W.Florek (red.), Geologia i geomorfologia pobrzeża i południowego Bałtyku, Pomorska Akademia Pedagogiczna, Słupsk, 10: 81-98.

Montreuil A-L., Bullard J.E., Chandler J.H., 2013. Detecting seasonal variations in embryo dune morphology using a terrestrial laser scanner. W: D.C.Conley, G.Masselink, P.E.Russell, T.J. O’Hare (eds.), Proceedings $12^{\text {th }}$ International Coastal Symposium, Plymouth, England, Journal of Coastal Research, SI 65: 1313-1318.

Pardo-Pascual J.E., García-Asenjo L., Palomar-Vázquez J., Garrigues-Talens P., 2005. New Methods and Tools to analyze beach-dune system evolution using a Real-Time Kinematic Global Positioning System and Geographic Information Systems. Journal of Coastal Research SI 49: 34-39.

Pilecki R., 2012. Zastosowania naziemnego skanera laserowego. Czasopismo Techniczne 26(109): 223-233.

Pye K., Blott S.J., 2008. Decadal-scale variation in dune erosion and accretion rates: an investigation of the significance of changing storm tide frequency and magnitude on the Sefton coast, UK. Geomorphology 102: 652-666.

Rosa B., 1963. O rozwoju morfologicznym wybrzeża Polski w świetle dawnych form brzegowych. Studia Societatis Scientarum Torunensis $\mathrm{V}: 1-172$. 